\title{
All Aboard!! - Legal AND CoMmercial IsSUeS IN TRANSPORTING CRUDE BY RAIL
}

\author{
KeIth ByblOW, DufFerin HARPER, AND PAUl BlysChaK*
}

The transportation of crude oil by rail has undergone significant growth in recent years, driven by a wide variety of actors and internal and external factors. This article surveys the dynamic legal and commercial context in which crude by rail operations occur, as well as the economic and regulatory forces working to keep the area in flux. In particular, these issues are considered in light of the tragedy that befell Lac-Mégantic in July 2013.
Le transport du pétrole brut par chemin de fer a considérablement augmenté au cours des dernières années. Cette hausse a été dictée par un certain nombre d'acteurs et de facteurs internes et externes. Cet article passe en revue le contexte juridique et commercial dynamique des opérations ferroviaires $d u$ brut ainsi que les forces économiques et réglementaires qui maintiennent la situation. Ces questions sont, tout particulièrement, examinées à la lumière de la tragédie de Lac-Mégantic en juillet 2013.

\section{TABLE OF CONTENTS}

I. INTRODUCTION AND OVERVIEW . . . . . . . . . . . . . . . . . . . . . . . . . 285

II. THE CRUDE BY RAIL INDUSTRY — RECENT GROWTH, the Players, the Drivers, and the PROJects $\ldots \ldots \ldots \ldots \ldots . \ldots 287$

A. Recent Growth AND the Players $\ldots \ldots \ldots \ldots \ldots \ldots \ldots . \ldots . \ldots . \ldots 287$

B. THE DRIVERS . . . . . . . . . . . . . . . . . . . . . . . . . 287

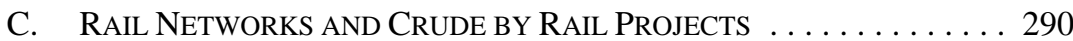

III. LEGAL REgiMES APPLICABLE TO THE

TRANSPORTATION OF CRUdE by RAIL . . . . . . . . . . . . . . . . . . . . . 294

A. TRANSPortation of DANGEROUS GoOdS LegisLation . . . . . . 295

B. EnVironmental PRotection LegisLAtion . ............. 298

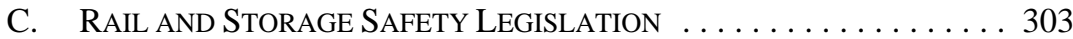

D. Potential Civil Liability to Third Parties $\ldots \ldots \ldots \ldots \ldots . \ldots 304$

E. REgUlatory DEVELOPMENTS AND

ReLATEd Legal Considerations . . . . . . . . . . . . . . 308

F. Legal Liability CASE Study: LaC-MÉGANTIC $\ldots \ldots \ldots \ldots . \ldots 314$

IV. Contractual ARRANGEMENTS IN CRUde By Rail

AND A SURVEy of SELECT ISSUES $\ldots \ldots \ldots \ldots$. . . . . . . . . . . . . . . . 318

A. GOVERNing AgREEMENTs $\ldots \ldots \ldots \ldots \ldots \ldots \ldots \ldots \ldots$

B. Discussion of Select IsSUeS $\ldots \ldots \ldots \ldots \ldots \ldots \ldots \ldots \ldots \ldots \ldots \ldots \ldots$

V. CONCLUding Remarks . . . . . . . . . . . . . . . . . . . . . . . . 330

\section{INTRODUCTION AND OVERVIEW}

It has become increasingly common over the last several years to open the business section of a major Canadian newspaper and find an article addressing the transportation of crude oil by rail. Whether tragic events like the calamity that befell Lac-Mégantic, Quebec

Keith Byblow and Dufferin Harper are partners at Blake, Cassels \& Graydon LLP, and Paul Blyschak is an associate at the firm. The authors would like to thank David Mercier of MEG Energy, Dan Dubois and Nathan Baines of Imperial Oil, and Nathan Zaseybida, associate with Blakes, for their valuable comments on and contributions to the preparation of this article. 
in July of 2013, or the particulars of new containment and testing requirements, the transportation of crude by rail and the various issues associated with it have become front of mind in Canada and in North America as a whole. This article seeks to canvas these various issues in greater detail, focusing, in particular, on certain legal and commercial aspects related to the transportation of crude by rail.

Considered first in Part II are the different crude by rail project participants, as well as the drivers pulling these different players to the crude by rail sector. We next discuss the rail infrastructure system in which Canadian crude by rail projects take place, before canvassing a number of different publicly disclosed crude by rail projects, including: (1) projects operated solely by midstream oil and gas service providers; (2) projects jointly undertaken by midstream service providers and upstream oil and gas producers; and (3) projects undertaken solely by producers or refiners.

Part III of this article surveys the different legal regimes and related obligations and liabilities imposed on crude by rail project participants. This begins with the examination of federal and provincial transportation of dangerous goods legislation and railway safety legislation. Examination of the potential application of environmental protection legislation and regulation to the transportation of crude by rail follows next. We also survey common law causes of action directly relevant to the transportation of crude by rail, as well as recent developments in the regulation of the transportation of crude by rail. Concluding this section, we look back on the Lac-Mégantic disaster and the subsequent class action proceedings filed against Montreal Maine \& Atlantic, as well as against various upstream, midstream, and downstream oil and gas companies associated with the Lac-Mégantic shipment.

Part IV of this article canvasses the different contractual agreements and arrangements pursuant to which crude by rail project participants structure their relationships. This can include construction, ownership and operating agreements, rail terminal services agreements and transloading services agreements, various ancillary agreements relevant to many crude by rail projects (including tanks storage/services agreements and interconnection agreements), and rail transportation agreements. The section investigates a number of more specific issues related to the transportation of crude by rail, with particular attention paid to the different means by which risks and liabilities are contractually allocated between crude by rail project participants. This begins with a review of the authority of regulators to interfere in the transportation of crude by rail, and is followed by: (1) a review of past instances in which public groups, including First Nations groups, have attempted to interfere in railway operations through the erection of blockades; and (2) the rights and reactions of railways companies where such blockades have arisen.

In total, the transportation of crude by rail involves a wide variety of legal and commercial considerations, not all of which can be considered in detail in a single academic article. Furthermore, as will be clear from the discussion that follows, the economic and regulatory forces shaping the growth of crude by rail remain in flux as new developments trigger and inform public opinion as well as industry and government reaction. By simple example, the finalization of this article for initial publication was contemporaneous with a further delay by the United States Department of State in its decision regarding the Keystone XL Pipeline, the announcement by Transport Canada of a series of important directives targeting railcar 
standards and route planning, and the derailment and explosion of a crude rail shipment in Lynchburg, Virginia. Against this backdrop, the main goal of this article is therefore to survey and bring together the most material commercial and legal considerations relevant to this new and currently very dynamic area of law and legal practice.

\section{The Crude by Rail Industry - REcent Growth, the Players, THE DRIVERS, AND THE PROJECTS}

\section{A. Recent Growth ANd the Players}

The crude by rail industry has undergone remarkable growth in recent years. According to the Transportation Safety Board of Canada, crude oil shipments by rail grew to approximately 160,000 carloads in 2013, from only 500 carloads in 2009. ${ }^{1}$ Crude rail shipments in the United States have experienced a similar growth curve, increasing to approximately 400,000 in 2013 from 10,800 in 2009. This exponential increase is also captured in export figures tallied by the National Energy Board, whose records state that crude exports from Canada by rail grew from 256,434 $\mathrm{m}^{3}$ in 2011, to 2,654,711 $\mathrm{m}^{3}$ in 2012, and reached $7,351,345 \mathrm{~m}^{3}$ in $2013 .^{2}$

This burgeoning crude by rail industry involves many players, which of course includes railway companies (the rail transportation service providers, including both federal and provincial railway companies). It also includes facility operators, namely midstream service providers with the personnel, experience, and networks capable of designing, constructing, and operating crude by rail facilities (those various facilities where crude is received and stored prior to being loaded into rail tank cars for transport). This may also involve intermediary service providers, such as trucking companies engaged to haul crude from the point of production to crude by rail storage facilities, or transloading facilities where no local or regional pipeline infrastructure exists or is available. Refiners reside at the downstream end of the crude by rail supply chain as the recipients of crude by rail shipments. In many ways, they represent the "demand" side of the crude by rail equation.

\section{B. THE DRIVERS}

Notwithstanding the broad scope of industry participants relevant in this expanding economic sector, there can be little doubt that the main drivers of the growth of crude by rail over the last half decade have been crude oil producers (the oil and gas companies that need to secure diversified, reliable, and economical means of supplying their product to buyers). In this regard, the drivers pushing such producers to transport their product by rail over recent years can be categorized as "external” and "internal."

$1 \quad$ Transportation Safety Board of Canada, News Release, “TSB and NTSB call on Canadian and U.S. regulators to improve the safe transportation of crude oil by rail” (23 January 2014), online: Transportation Safety Board of Canada <www.tsb.gc.ca/eng/medias-media/communiques/rail/2014/ r13d0054-20140123.asp>.

National Energy Board, “Canadian Crude Oil Exports - By Export Transportation System Summary - 5 year trend,” online: National Energy Board <https://www.neb-one.gc.ca/nrg/sttstc/crdlnd ptrlmprdct/stt/archive/cndncrdlxprttrnsprttnsstm5yr/cndncrdlxprttrnsprttnsstm5yrrchv-eng.html>. 


\section{EXTERNAL DRIVERS}

The most significant external factor is increasingly limited pipeline capacity. Simply put, the output of western Canadian and American producers has outpaced the capacity of North American pipeline infrastructure. That said, constraints on pipeline capacity are not solely the result of increased production. Pipeline capacity constraints are also being aggravated by a number of additional factors, including production allocation and apportionment, as well as the rationalization of Canadian refining capacity. ${ }^{3}$ The transportation of crude by rail is increasingly being sought as a means to remedy or circumvent these constraints, whether by providing new routes to the same refining capacity or by providing access to an expanding portfolio of refineries, including by means of coastal access or cross-border shipments.

However, it is not just the simple delta between current crude production and current pipeline capacity pushing producers to transport their product by rail. Producers have also been turning to rail in apprehension of relatively novel inhibitors to the ability of North American pipeline companies and their infrastructure and transmission assets to accommodate growing crude production on a go-forward basis. In particular, customary inhibitors to the development and construction of new pipeline infrastructure, including land access and spill mitigation and response concerns, are increasingly being joined by additional barriers to development typically reserved more for upstream producers as public interest groups, such as environmental activists, strive to identify increased pipeline capacity as a causal factor that will lead to increased production. In other words, whereas pipeline companies were once generally only tasked with arguing for the commercial necessity of new infrastructure or a proposed route, they are increasingly being tasked (at least in the forum of wider public opinion) to defend increased oil and gas production, and the oil and gas industry itself, in respect of broader public policy issues, including but not limited to the desirability of reducing carbon emissions, a fact to which each of TransCanada (Keystone XL), Enbridge (Northern Gateway), and Kinder Morgan (Trans Mountain) can now readily attest. This anticipation of future pipeline infrastructure delay, or (in some cases) anticipation of outright denial, is also an important motivator pushing the oil and gas industry to invest in and commit to the projects necessary to provide a meaningful rail alternative.

\section{INTERNAL DRIVERS}

There are various "internal” drivers commonly cited by producers for choosing to transport crude by rail in addition to, or in the place of, transportation by pipeline that do not often get attention in the public forum but which nonetheless deserve appreciation.

The transportation of crude by rail often offers dispatchability and scalability advantages. These can allow producers to match rail services to growing or new transportation needs, as may be applicable, and to allow for shipment to market with the highest netback. Crude by rail can also offer flexibility advantages not otherwise or previously readily available in the transportation of crude. Apart from arrangements where one or more producers might enter into commitments that underpin the construction of new rail loading facilities, long-term take 
or pay contracts are generally not required in connection with the transportation of crude by rail. Even those producers that are entering into long-term take or pay or similar commitments to underpin the construction of new rail loading facilities can negotiate optionality into the terms of such commitments, having particular regard for the availability to market facility capacity to other users on a spot or short-term basis or to subcontract their capacity. Crude by rail can also offer producers the opportunity to reduce or avoid discounts to Western Canadian Select benchmark prices by railing oil to markets with increased demand.

From a product specification standpoint, the transportation of crude by rail allows producers to maintain the purity and uniformity of crude products through shipments in batches, as opposed to the commingling that generally occurs in the transportation of crude by pipeline. The transportation of crude by rail also does not require the addition of diluent as does the transportation of crude by pipeline. Nor is rail transport confined to select or restricted varieties of product; crude capable of being transported by rail includes conventional sweet, conventional heavy, distressed high TAN (sour) oil sands bitumen, dilbit, and various blends. Neither does the transportation of crude by rail necessarily take an inordinate amount of time relative to transportation by pipeline, with transit times from Edmonton to Vancouver, for example, taking as little as 48 hours.

Depending on the circumstances, the transportation of crude by rail can also be low cost relative to the transportation of crude by pipeline, particularly where large expenditures may first be necessary in connection with transportation by pipeline. This is because the transportation of crude by rail is largely conducted by the use of existing railway infrastructure and existing rights-of-way, and therefore precludes the necessity of engaging with stakeholders and landholders as may be required in connection with the construction of new pipelines. Furthermore, where new rail infrastructure is needed, such infrastructure generally does not require the same regulatory applications and approvals typically required in connection with significant new pipeline infrastructure, making crude by rail projects free from much of the initial regulatory risk faced by pipelines and therefore potentially easier to both plan and build. It is also important to appreciate that a number of factors have been contributing to increased pipeline transportation costs in recent years, including more stringent regulatory conditions, further increasing the competitiveness of rail transport vis-àvis pipeline. ${ }^{4}$

In total, the Railway Association of Canada argues that the internal drivers of crude by rail will continue to attract producers to rail transportation even in the event that approval and construction of new pipeline infrastructure reduces the force of external drivers, a point that a number of senior midstream executives have readily agreed with. ${ }^{5}$ This is a clear suggestion that the transportation of crude by rail will likely remain an integral component of the midstream oil and gas sector for the foreseeable future. In fact, some projections anticipate

$4 \quad$ Jeff Lewis, “Cost of oil transported by pipelines up 60\% in five years, NEB says” Financial Post (16 April 2014), online: <business.financialpost.com/2014/04/16/cost-of-oil-transported-by-pipelines-up-60in-five-years-neb-says/>.

Eric Atkins, "Proposed pipeline projects no threat to oil-by-rail business" The Globe and Mail (3 April 2014), online: <www.theglobeandmail.com/report-on-business/industry-news/energy-and-resources/ pipeline-projects-no-threat-to-oil-by-rail-business/article17807595>. 
rail capacity in the Western Canadian Sedimentary Basin to double from approximately 550,000 barrels per day (bpd) in early 2014, to 1 million bpd by the end of 2014 and to approximately 1.5 million bpd by the end of 2015 . $^{6}$

\section{RAIL NeTworks AND Crude by Rail Projects}

\section{RAIL NETWORKS}

Like the transportation of crude by pipeline, the transportation of crude by rail involves a patchwork of interconnecting and overlapping infrastructure, composed of both large national service providers and small regional or provincial players.

Canadian National Railway (CN Rail) and Canadian Pacific Railway (CP Rail), for example, have North American operating destination sites, distribution centres, and transloading facilities from Sexsmith (Alberta) to Stoughton (Saskatchewan) to Tacoma (Washington) to Dartmouth (Nova Scotia) to Prince Rupert (British Columbia) to Hay River (Northwest Territories) to Montreal (Quebec) to Chicago (Illinois) to New Orleans (Louisiana) to Kansas City (Kansas) and to Mobile (Alabama).

Complementing these larger federal carriers are the services of small provincial operators and railway lines. According to the Alberta Ministry of Transportation, for example, the province has approximately 310 industrial railways, five heritage railways, and two public railways which are provincially regulated and which facilitate the movement of approximately 70 million tons of goods within the province each year, including, in addition to petroleum products, forest, agricultural, and consumer products. Saskatchewan houses more than 2,000 km of railways under provincial jurisdiction, including short line railways and localized industrial railways.

In total, prominent Canadian oil-producing regions currently served by the combination of these federal and provincial railway networks include the Viking, Cold Lake, Athabasca, Peace River, Lloydminster, and Bakken areas, to name a few. That said, the transportation of fuel oils and crude composed only approximately 5 percent of goods transported by rail in Canada in the fourth quarter of 2013, a figure that some may find surprising given the amount of attention paid to the transport of crude by rail over recent years, as well as a clear implication that the crude by rail sector still has much room to grow. ${ }^{7}$

\section{CRUDE BY RAIL PROJECTS}

There is no such thing as a "standard” crude by rail project. Stated differently, there is no single manner in which crude by rail projects are either planned or pursued. Rather, the components of crude by rail projects, including their location, the type of facilities involved,

6 Yadullah Hussain, "Rail set to transport 500,000 bpd of Canadian oil by year-end but costs remain high" Financial Post (17 April 2014), online: <business.financialpost.com/2014/04/17/rail-set-to-transport500000-bpd-of-canadian-oil-by-year-end-but-costs-remain-high/> .

Statistics Canada, "Railway carloadings statistics, by commodity: monthly” (Table 404-0002, CANSIM database), online: Statistics Canada <www5.statcan.gc.ca/cansim/pick-choisir?lang=eng\&p2=33\&id= 4040002>. 
the project participants, and the project governance structure, vary greatly depending on the circumstances, including, in particular, the needs of the producer(s) involved, as well as existing and available transportation and storage infrastructure.

It is useful to consider each project with regard to the participating players. Crude by rail projects may be undertaken exclusively by one or more oil and gas midstream service providers. Crude by rail projects can be undertaken jointly by one or more service providers and one or more producers. Alternatively, crude by rail projects may be undertaken by producers or refiners without any meaningful participation by a midstream service provider. A survey of several recent crude by rail projects in western Canada is illustrative of these various approaches and project structures.

\section{a. Midstream Service Provider Crude by Rail Projects}

In August 2013, TORQ Transloading Inc. (TORQ) announced its planned development of a large scale unit train, crude by rail terminal in the Kerrobert, Saskatchewan area to be served by CP Rail. ${ }^{8}$ The press release states that TORQ is negotiating multiple pipeline connections to accommodate delivery of both light and heavy crudes to the Kerrobert rail terminal, and that the terminal will be engineered to handle two 120-car unit trains per day (or up to 168,000 bpd) and is expected to cost approximately \$100 million. The press release additionally states that the Kerrobert rail terminal is being designed to also handle truckdelivered crude volumes, such truck-delivered volumes to be delivered to the terminal's storage tanks, expected to include up to 500,000 barrels of storage comprised of a mixture of both heated (for undiluted heavy crude) and non-heated storage. According to TORQ, the terminal is also being designed to receive inbound, rail back-hauled condensate and is expected to commence operations in the third quarter 2014.

In August 2013, by comparison, Gibson Energy Inc. (Gibson) and U.S. Development Group LLC (USDG) (a Houston-based developer of rail terminal facilities and logistics) announced their commitment to construct a unit train rail loading facility near Hardisty, Alberta, with pipeline connectivity from Gibson's Hardisty terminal. ${ }^{9}$ Press releases for the project indicate that crude handled at the new Hardisty rail terminal will be sourced exclusively by pipeline from Gibson's existing Hardisty terminal, located approximately five kilometres away, and will be served by CP Rail's North Main Line. The parties also state that the Hardisty rail terminal will be capable of handling two unit trains per day of up to 120 railcars each, and that the terminal will consist of a fixed loading rack with 30 railcar loading positions, as well as a unit train staging area and track loops capable of housing up to five unit trains. In connection with the project, Gibson has committed to install additional pumping equipment as well as construct a pipeline necessary for the transfer of crude from its existing Hardisty terminal to the new crude by rail facility. Press releases made by the

$8 \quad$ TORQ Transloading Inc, News Release, “TORQ Transloading to Construct State-of-the-Art Pipeline Connected Unit Train Crude-by-Rail Terminal at Kerrobert, Saskatchewan” (14 August 2013), online: TORQ Transloading <www.torqtransloading.com/news_releases.cfm?id=5>.

Gibson Energy Inc, News Release, “U.S. Development Group Partners With Gibson Energy to Develop Crude-By-Rail Terminal Near Hardisty, Alberta” (6 August 2013), online: Gibsons Energy Inc $<$ www.gibsons.com/Investors/News-Item-New.aspx?id=1747343 $>$. 
parties in connection with the project state that term contracts with four investment grade customers for approximately 100,000 bpd underpin the investment.

Similarly, in July 2013, Keyera Corp. (Keyera) and Kinder Morgan Energy Partners, LP (Kinder Morgan) announced a fifty-fifty joint venture to construct a crude oil rail loading facility in Edmonton, Alberta, that when complete will be able to accommodate crude oil streams handled at Kinder Morgan's Edmonton terminal for loading and transportation by rail. ${ }^{10}$ The new terminal is to be constructed adjacent to Keyera's Alberta Diluent Terminal, will be operated by Keyera, and will house 20 loading spots capable of loading approximately 40,000 barrels of crude oil per day into tank cars to be serviced by both CP Rail and CN Rail. Both of the companies are also engaged in modifications to their respective storage and transportation facilities in the Edmonton area to facilitate delivery of crude oil to the new terminal. In particular, Keyera is proposing to construct a new 12-inch diameter condensate pipeline to connect the new terminal to Keyera's Fort Saskatchewan pipeline system. Kinder Morgan, for its part, has proposed the construction of a 16-inch diameter pipeline to connect the new facility to its North Forty Edmonton terminal. Various other additional connectors will need to be installed, as well as additional pumping capacity. Construction of the new terminal is to be undertaken further to a five-year agreement with an unidentified major refiner.

Throughout 2012 and 2013, Canexus Corporation (Canexus) expanded its existing truck to rail (manifest) transloading facility, located near Bruderheim, Alberta, to include a large scale, pipeline connected unit train crude by rail terminal. ${ }^{11}$ Canexus' public documents and website indicate that, when fully operational, the terminal is expected to load approximately 10.5 unit trains per week. Canexus has long-term agreements in place with MEG Energy, Cenovus, and a midstream logistics and marketing company for unit train service at the terminal, and the Canexus terminal has access to both CN Rail and CP Rail lines.

\section{b. Joint Producer and Service Provider Crude by Rail Projects}

In December 2013, Kinder Morgan and Imperial Oil (Imperial) announced a fifty-fifty joint venture to build a crude oil rail-loading facility in Strathcona County, Alberta. ${ }^{12}$ The parties announced that the facility will be built on land approximately half a kilometre southwest of Kinder Morgan's existing Edmonton storage terminal, on land adjacent to Imperial's existing Strathcona refinery. The press release further provides that the new Edmonton rail terminal will be designed as a crude oil loading terminal capable of loading one to three unit trains per day totaling 100,000 bpd at start-up, with the potential to expand to approximately 210,000 bpd and, ultimately, potentially up to 250,000 bpd. The parties state that the terminal will be connected by a new pipeline to Kinder Morgan's local tank

$10 \quad$ Keyera Corp, News Release "Keyera and Kinder Morgan to Construct Crude Oil Rail Loading Terminal in Edmonton” (30 July 2013), online: Keyera Corp <https://www.keyera.com/titanweb/keyera/webcms. nsf/AllDocs/CAED222B1A53844687257BB8007389A7?OpenDocument>.

11 Canexus Corporation, “North American Terminal Operations: Multi-Phase Expansion Plans,” online: Canexus Corporation <canexus.ca/operations/north-american-terminal-operations/multi-phase-expan sion>.

12 Kinder Morgan Energy Partners, LP and Imperial Oil, Press Release: "Kinder Morgan and Imperial Oil to Build Edmonton Crude Oil Rail Terminal” (20 December 2013), online: Kinder Morgan <phx. corporate-ir.net/phoenix.zhtml?c=119776\&p=irol-newsArticle\&ID=1886545>. 
facility and will be capable of sourcing all crude streams handled by Kinder Morgan for delivery by rail to North American markets and refineries. The new Edmonton rail terminal will be constructed and operated by Kinder Morgan and will connect to both CN Rail and CP Rail main lines.

Kinder Morgan and Imperial in their joint press release stated the following, citing Rich Kruger, the chairman, president, and chief executive of Imperial:

\footnotetext{
"The terminal will deliver additional infrastructure and options required for our distribution network and help maintain the value of Canadian crude [and that] additional transportation capacity will be used for current and future production from the Kearl Oil Sands project, including the expansion phase, which will come on stream in late 2015.”
}

Imperial Oil will be the base load customer and has subscribed for the start-up capacity through a long-term contract. The partners are now actively marketing possible expansion capacity to potential third-party customers. Investment by the joint venture partners for the rail terminal will total approximately $\$ 170$ million. In addition, Kinder Morgan will invest approximately \$100 million in pipeline connections and two new staging tanks to be constructed within the Kinder Morgan Edmonton storage facility. Construction is now underway and completion is scheduled for December $2014 .{ }^{13}$

Another example of a joint producer and service provider crude by rail project is that announced by Tundra Energy Marketing Limited (TEML) in October 2012. ${ }^{14}$ Notably, this project involved the company initially pairing only with CN Rail rather than a "midstream" oil and gas service provider. In particular, the companies announced their intention to construct a crude oil railcar loading terminal near Cromer, Manitoba. The parties announced that the terminal would initially load 30,000 bpd onto rail tank cars for transport (the equivalent of more than 50 tank cars) and that it was expected that the facility would be operational in the second quarter of 2013. The parties also announced that the facility will be designed to have the potential to accommodate a unit train of 100 tank cars, with each train carrying approximately 60,000 bpd of crude oil. TEML markets crude on behalf of various producers in the Williston Basin, including its parent company, Tundra Oil \& Gas Partnership. The facility is also intended to serve crude producers operating in the Bakken. In January 2014, Enbridge Income Fund announced its plans to build a pipeline connecting the facility with its Enbridge Pipelines (Saskatchewan) Inc. system. ${ }^{15}$

\section{c. Crude by Oil Projects Not Involving Midstream Service Providers}

According to its Annual Information Form (AIF) dated 11 March 2014, Crescent Point Energy Corp. (Crescent Point) owns and operates four railcar loading facilities serving its production in central Alberta, southeast Saskatchewan, southwest Saskatchewan, and the

$13 \quad$ Ibid.

CN \& Tundra Energy Marketing Limited, News Release, "CN and Tundra Energy Marketing to construct crude oil rail car loading terminal in Manitoba” (18 October 2012), online: Tundra Oil and Gas $<$ tundraoilandgas.com/images/CN-Tundra\%20Energy-Final.pdf >.

15 Enbridge Income Fund Holdings, News Release, "Enbridge Income Fund Approves Pipeline Connection to Tundra Rail Terminal at Cromer, Manitoba” (29 January 2014), online: Enbridge Income Fund Holdings <www.enbridgeincomefund.com/Read-the-Latest-News/News-Releases.aspx\#yearTab=en 2014\&id=1803246>. 
State of Utah. According to the company, these rail transportation operations assist it in mitigating crude oil basis risk "by delivering a portion of [the company's] crude oil production into diversified refinery markets." 16 The AIF indicates that "[c]rude oil volumes loaded at these facilities are sold at the loading facilities and [the company's] buyers are responsible for providing railcars and managing transportation logistics from that point until delivery at the refinery gate. ${ }^{17}$ Crescent Point credits its crude by rail operations with giving it the ability "to access refining markets that are not pipeline connected"18 and to thereby diversify the company's price and market risk by reducing its exposure to volatility in Canadian crude oil differentials. Crescent Point further credits its crude by rail projects with giving it the ability to increase and diversify the number of counterparties with which it transacts, thereby assisting it in managing its credit risk exposure.

By contrast, in 2012 Chevron announced its intention to construct crude by rail transloading facilities at its Burnaby Refinery outside of Vancouver. ${ }^{19}$ Although the refinery has predominantly relied on Kinder Morgan's Trans Mountain Pipeline for its crude oil feedstock since the pipeline was built in 1954, the company stated that price differentials between overseas and North American markets have resulted in historically high pipeline demand from shippers located outside of British Columbia, significantly curtailing the amount of crude available to Chevron at the Burnaby refinery. The transloading facilities were therefore designed to increase the refinery's ability to receive crude by rail and to supplement quantities being trucked to the refinery. Transloaded rail to truck crude shipments began in May 2012, and were initially limited to 2,500 bpd with a maximum potential of 6,000 bpd. The crude by rail transloading facilities were designed to accommodate 8,000 bpd. Chevron has stated that greater crude by rail receiving capacity was desired, but that it was limited by logistical and infrastructure issues at the refinery. ${ }^{20}$

The foregoing sampling should serve as clear evidence of the force of the drivers behind the crude by rail industry and the commitment of the industry players to this method of transportation. As such, we now turn to a consideration of the legal regimes applicable to the industry.

\section{LEGAL REgIMES APPLICABLE TO THE Transportation OF CRUDE BY RAIL}

While there are a multitude of interrelated legal and commercial issues involved in the transportation of crude by rail, none garner nearly as much attention as those involving safety and the environment. This is not surprising. Although the Railway Association of Canada claims that 99.9977 percent of all dangerous goods shipments by rail reach their destination

rescent Point Energy Corp, Annual Information Form For the Year Ended December 31, 2013 (11 March 2014), online: Crescent Point Energy <www.crescentpointenergy.com/files/18550.FINAL-AIF\%202013.pdf $>$ at 13 .

Ibid.

Ibid.

“Oil brought by rail, truck to Burnaby refinery” CBC News (16 July 2013), online: <www.cbc.ca/ news/canada/british-columbia/oil-brought-by-rail-truck-to-burnaby-refinery-1.1309612>.

Chevron, "Chevron Burnaby Refinery: Crude Supply Overview" (Neighbourhood CAP Meeting presentation, 21 November 2012), online: Chevron <www.chevroncap.com/files/documents/Attachment -2-Burnaby-Refinery-Crude-Supply-Overview_Nov212012.pdf $>$. 
without accidental release ${ }^{21}$ it nonetheless remains the case that where accidents during the course of the transportation of crude by rail do occur, they are capable of having disastrous consequences and resulting in potential liability under a variety of legislative regimes, as well as under the common law.

\section{A. Transportation OF DANGERous Goods LEgislation}

Perhaps the legal regime of the most immediate relevance to the transportation of crude by rail is transportation of dangerous goods legislation, in particular the federal regime established by the Transportation of Dangerous Goods Act, $1992^{22}$ and the Transportation of Dangerous Goods Regulations. ${ }^{23}$ The purpose of the TDGA and TDGR is to promote public safety during the transportation of dangerous goods by all modes of transport in Canada, including by rail. Towards this end, these statutes set out various requirements for the packaging, labelling, and containment of dangerous goods, including crude oil, as well as associated training obligations, emergency response plan requirements, duties to report and remediate releases of dangerous goods, offences, penalties, and defences. ${ }^{24}$

Transport Canada has the authority to develop and enforce TDGA and TDGR requirements and restrictions, while the Transport of Dangerous Goods Directorate is charged with monitoring compliance by conducting inspections and investigations. Also, while each province and territory has its own transportation of dangerous goods legislation, it is important to note that such legislation generally adopts, in whole or in part, the federal regulations, ${ }^{25}$ greatly simplifying and streamlining transportation of dangerous goods compliance requirements. Moreover, the administration of the TDGA is generally coordinated between the provinces, territories, and the federal government pursuant to intergovernmental agreements entered into between these different jurisdictions. ${ }^{26}$ In total, it has been noted that " $\mathrm{t}$ ] he TDGA appears to have provided an effective framework for interjurisdictional cooperation in a field where coordination among jurisdictions and among agencies is a central element of an effective regulatory regime.”27

At the heart of the TDGA lies a broad and encompassing prohibition. Section 5 of the TDGA provides as follows:

Railway Association of Canada, "Safely Transporting Energy Products,” online: Railway Association of Canada <www.railcan.ca/assets/images/Safely_Transporting_Energy_Products_Fact sheet_FIN AL.pdf $>$ at 2.

22 SC 1992, с 34 [TDGA].

23 SOR/2001-286 [TDGR].

24 Dangerous goods are defined as "a product, substance or organism included by its nature or by the regulations in any of the classes listed in the schedule [to the TDGA].” Crude oil generally falls under Class 3, "Flammable and combustible liquids." See TDGA, supra note 22, s 2 and Schedule.

$25 \quad$ See e.g. Dangerous Goods Transportation and Handling Regulation, Alta Reg 157/1997, s 2(1) which provides that the TDGR are adopted with full force for the purposes of the Dangerous Goods Transportation and Handling Act, RSA 2000, c D-4.

26 Such coordination is explicitly contemplated by the legislation (see TDGA, supra note 22, s 4). Given such coordination and streamlining between the provinces, territories, and the federal government, for the sake of brevity this article will focus on the federal transportation of dangerous goods regime rather than any provincial or territorial regime.

27 Jamie Benidickson, Environmental Law, 4th ed (Toronto: Irwin Law, 2013) at 288, citing Murray Rankin, “Dangerous Moves: The Law Responds to the Transportation of Dangerous Goods” (1990) 24:2 UBC L Rev 191. 
No person shall import, offer for transport, handle or transport any dangerous goods unless

(a) the person complies with all safety requirements and security requirements that apply under the regulations;

(b) the goods are accompanied by all documents that are required under the regulations;

(c) a means of containment is used for the goods that is required or permitted under the regulations; and

(d) the means of containment and means of transport comply with all safety standards that apply under the regulations and display all applicable safety marks in accordance with the regulations. ${ }^{28}$

The reach of this provision is also greatly extended by the defined terms contained therein. The term "offer for transport," for example, is defined broadly to mean

for dangerous goods not in transport, to select or allow the selection of a carrier to transport the dangerous goods, to prepare or allow the preparation of the dangerous goods so that a carrier can take possession of them for transport or to allow a carrier to take possession of the dangerous goods for transport. ${ }^{29}$

The term "handling," on the other hand, is defined broadly to include "loading, unloading, packing or unpacking dangerous goods in a means of containment for the purposes of, in the course of or following transportation and includes storing them in the course of transportation." ${ }^{30}$

The TDGR is similarly expansive in its reach, including through its definition of, and those requirements imposed on, “consignors.” This term captures

a person in Canada who

(a) is named in a shipping document as the consignor;

(b) imports or who will import dangerous goods into Canada; or

(c) if paragraphs (a) and (b) do not apply, has possession of dangerous goods immediately before they are in transport. ${ }^{31}$

Obligations imposed on "consignors" include that they: (1) "determine the classification of dangerous goods" before allowing a carrier to take possession of the goods; ${ }^{32}(2)$ ensure that imported dangerous goods "have the correct classification before they are transported in Canada"; ${ }^{33}$ and (3) prepare and deliver to carriers all required classification information and shipping documents prior to allowing the carrier to take possession of dangerous goods. ${ }^{34}$

Supra note 22.

TDGR, supra note 23, s 1.4 .

TDGA, supra note 22, s 2.

TDGR, supra note 23, s 1.4 .

Ibid, s 2.2 .

Ibid.

Ibid, s 3.1(1). 
In total, the combined application of the TDGA and the TDGR results in a broad web of often overlapping definitions and obligations capable of capturing the full spectrum of players in the crude by rail space in a number of different ways. This inclusive approach is generally considered to be in the public interest, and has been noted by Canadian courts on a number of different occasions. In $R$. v. Snap-On Tools of Canada Ltd., for example, Justice Kastner explained that "[t]he legislation clearly contemplates that the transportation of dangerous goods is not a finite transaction completed when the shipper parcels an item and delivers it to the carrier. It is a continuum that commences at the packing of the item and continues through to the unpacking of the item at its destination."35 Amongst other things, this is a clear implication that Canadian courts may not be reluctant to hold a party responsible for the fate of dangerous goods even long after it has left the party's hands.

Although defensible on a number of grounds, this is a potentially onerous approach. Strict compliance with the TDGA and the TDGR can, at times, present a number of significant practical difficulties and administrative burdens. The consistent correct classification of crude oil, for example, can present a number of different challenges. First, while the TDGR previously provided that a consignor may use the classification that was determined by a previous consignor, this provision was repealed in June $2014 .{ }^{36}$ Second, natural variability in the characteristics of crude oil, including the presence of dissolved natural gas or hydrogen sulphide, and the commingling of different crude oils during loading, transport, or storage has the potential to make classification even more difficult, particularly for transloading operators receiving crude from different producers or different production areas. Third, sampling methods and testing procedures may be subject to limitations with respect to crude oil, which could lead to inaccuracies in packing group designations. ${ }^{37}$

The risk presented by such obligations and associated practical difficulties manifest in a number of different ways, including through those penalties applicable under the TDGA and TDGR. In particular, section 33(2) of the TDGA provides that any person who contravenes a provision of the TDGA or the TDGR is liable on indictment to imprisonment for a term not exceeding two years, or is liable on summary conviction to a fine not exceeding $\$ 50,000$ for a first offence and not exceeding $\$ 100,000$ for each subsequent offence. However, such potential liability is balanced by due diligence defences available under the TDGA, including sections 20 and 40. Amongst other things, these sections provide that no person "shall be found guilty of an offense if it is established that the person took all reasonable measures to comply with [the TDGA] or to prevent the commission of the offence.”38

Potential liability in connection with the transportation of dangerous goods also manifests in duties to remediate spills or releases of dangerous goods. Section 19 of the TDGA enables an inspector to issue a direction to a person to remediate the impacts of a release of

35 (2001), 44 CELR (NS) 301 at 306 (Ont Ct J).

36 Regulations Amending the Transportation of Dangerous Goods Regulations (Update of Standards), SOR/2014-152.

37 See Transportation of Dangerous Goods General Policy Advisory Council, Testing and Classification Working Group, Submission and Recommendations: Strengthening the Testing and Classification Framework for Crude Oil by Rail (31 January 2014), online: Transport Canada <www.tc.gc.ca/media/ documents/tdg-eng/5806-2014-3479-F-BT8821720-CAPP-EDMS-238982-v1-Jan-31-14-GPAC-Test-Cen-rev-AAA.pdf>.

38 TDGA, supra note 22, s 40. 
dangerous goods in order to reduce any resulting danger to public safety. Furthermore, persons to whom a direction can be issued include persons who own the dangerous goods as well as those who have "charge, management or control” of the dangerous goods or their means of containment, ${ }^{39}$ a term which has been interpreted and applied very broadly by Canadian courts. ${ }^{40}$ The result is again a potentially wide range of persons who may be subject to remediation directions following the spill or release of crude being transported by rail, including the owner of the crude, railway carriers, and owners of the tank cars in which the crude has been stored. ${ }^{41}$

\section{B. EnVironmental Protection Legislation}

In the event of a derailment or collision, a spill or release of crude oil can, in addition to danger to public safety concerns under transportation of dangerous goods legislation, lead to significant environmental consequences, including the loss of life. ${ }^{42}$ The remediation of spills and releases is often overseen by provincial environmental authorities. Depending on the circumstances, liability for a railway release may also trigger liability pursuant to the federal Fisheries Act. ${ }^{43}$

Liability under most provincial environmental statutes generally takes two forms: (1) administrative liability pursuant to a ministerial order; and (2) quasi-criminal liability for violation of the applicable environmental statute or regulation. In addition, liability of officers and directors is also a significant concern in the environmental context. Finally, much like in the respect of the transportation of dangerous goods, environmental legislation pertaining to the remediation of spills and releases has generally been drafted, interpreted, and applied to cast a wide net of potential responsibility and liability.

\section{ADMINISTRATIVE LIABILITY}

In the event of a release of crude oil from a railcar in each of the provinces, the minister responsible for the environment (or other equivalent provincial minister) may issue a Ministerial Order requiring certain responsible persons to, among other things, eliminate or control the release of the contaminant, carry out clean-up operations, and conduct investigations into the cause of the release. In all of the provinces discussed herein, with the

III.B.2 of this article, below.

\section{Ibid, s 19(2)(a).}

whrudence addressing the term "charge, management or control,” see Part Concerns regarding federal and provincial overlap in the event of a spill incident involving the transportation of dangerous goods have resulted in intergovernmental agreements between the provinces and the federal government. See supra note 26. For example, the governments of Canada and Alberta have entered into an agreement entitled the "Canada-Alberta Agreement Respecting the Administration of the Transportation of Dangerous Goods Act, 1992”, online: Transport Canada <www.tc.gc.ca/eng/ tdg/clear-agreements-alberta-385.htm>. This agreement allocates responsibilities in respect of the requirements under the TDGA, TDGR, and the Dangerous Goods Transportation and Handling Act, RSA 2000, c D-4, including responsibility for: (1) spill response and remediation activities; (2) assessing and monitoring emergency response plans; (3) issuing permits and stop orders; and (4) inspection and enforcement activities. Alberta and Canada have also agreed to notify each other regarding the issuance of any protective directions or stop orders or in circumstances where either has received notification of an accident or imminent release.

See the discussion on the Lac-Mégantic disaster at Part III.F of this article, below.

RSC 1985, c F-14. It is beyond the scope of this article to describe the constitutional dichotomy of which jurisdiction will respond to a spill and when. Suffice to say, the provinces will often exercise jurisdiction over the remediation of spills from railways, typically in concert with federal departments. 
limited exception of British Columbia in certain circumstances, a Ministerial Order may be directed to the owner of a substance, either alone or in combination with persons having charge or control of the contaminant or the land upon which the release occurred. ${ }^{44}$ The impact of this ability is that the owner of crude oil being transported by rail, who otherwise has no other involvement with the rail transportation activities, retains liability in the event of a spill.

For example, in Alberta, pursuant to the Environmental Protection and Enhancement Act, a Ministerial Order can be issued against a "person responsible," the definition of which reads as follows:

“person responsible”, when used with reference to a substance or a thing containing a substance, means

(i) the owner and a previous owner of the substance or thing,

(ii) every person who has or has had charge, management or control of the substance or thing, including, without limitation, the manufacture, treatment, sale, handling, use, storage, disposal, transportation, display or method of application of the substance or thing,

(iii) any successor, assignee, executor, administrator, receiver, receiver-manager or trustee of a person referred to in subclause (i) or (ii), and

(iv) a person who acts as the principal or agent of a person referred to in subclause (i), (ii) or (iii). ${ }^{45}$

In addition to the above definition, in Alberta, in the context of Ministerial Orders, the owner of a substance is further defined as "the owner of the substance immediately before or during the release of the substance." 46

In the event of a spill or release, there are generally obligations both to report a release and remediate a release. In most provinces, including Alberta, the person that releases or causes or permits the release, such as the railway operator, is the person who has the duty to report the release. However, unlike the reporting obligation, the remediation obligation extends to “persons responsible” for the substance in question. For example, section 112(1) of the EPEA provides as follows:

Where a substance that may cause, is causing or has caused an adverse effect is released into the environment, the person responsible for the substance shall, as soon as that person becomes aware of or ought to have become aware of the release,

(a) take all reasonable measures to empower the director to issue an order against the owner of a substance unless the owner of the substance had, among other things, possession, charge or control of the substance at the time it was introduced or escaped into the environment. 
(i) repair, remedy and confine the effects of the substance, and

(ii) remediate, manage, remove or otherwise dispose of the substance in such a manner as to prevent an adverse effect or further adverse effect,

and

(b) restore the environment to a condition satisfactory to the Director. ${ }^{47}$

Pursuant to the above, arguably any of the railway operator, transloaders, tank car owners, or the owner of the crude oil may have obligations relating to remediation. The EPEA and most other provincial environmental statutes purposely cast a wide net of potential responsibility in relation to remediation, including to mitigate the possibility that the government will be left to absorb any remediation costs. Furthermore, there is generally no prescribed hierarchy of liability amongst the various categories of persons responsible. In practice, however, following a release, the government is likely to initially impose administrative liability obligations such as a Ministerial Order on the parties who are at fault for the release, such as the rail operator or other third party that may be responsible for the railway transportation. If, however, the parties at fault are unwilling or unable (due, for example, to insolvency) to fulfill their obligations, the government may extend those obligations to other persons that qualify within the definition of "person responsible" or any similar term that might be used in other provinces.

A Ministerial Order remains in effect until it is complied with or revoked by the issuing Minister. ${ }^{48}$ Once named in a Ministerial Order, launching a successful appeal can be extremely difficult. Unless a person can argue that it does not fall within the definition of "person responsible," that person will generally be unable to extricate themselves from a Ministerial Order. ${ }^{49}$ With limited exceptions, such as environmental emergencies under the Canadian Environmental Protection Act, $1999,{ }^{50}$ there is also generally no due diligence defence $^{51}$ or "act of God" defence that can be raised as a basis to avoid liability under a Ministerial Order. Liability under a Ministerial Order is not fault-based. Indeed, Ministerial Orders against completely blameless parties have been upheld in circumstances where environmental work was necessary, and in these instances the environmental protection objective of environmental legislation has taken precedence over the "polluter pays" principle. $^{52}$

48 In some circumstances, the issuance of a Ministerial Order to a certain person, including an owner of a substance, may be appealable to the courts.

$49 \quad$ In Lac-Mégantic, both the parent railway company and the parent company to the one that owned the crude oil have appealed their inclusion in the Ministerial Order on the basis that they were solely shareholders in the subsidiary companies and thus did not fall within the class of persons to whom a Ministerial Order could be issued. See further discussion of Lac-Mégantic in Part III.F.2, below.

50 SC 1999, с 33, s 205 [CEPA].

51 Although due diligence is not a defence after a person has been named in a Ministerial Order, it may be of assistance in discussions with the respective environment department to avoid being named in a Ministerial Order prior to it being issued.

52 See Kawartha Lakes (City) v Ontario (Director, Ministry of the Environment), 2013 ONCA 310, 74 CELR (3d) 1 at para 12. 


\section{QUASI-CRIMINAL LIABILITY}

Environmental liability for a release of crude oil being transported by rail may also involve quasi-criminal liability under various provincial environmental statutes. For example, under section 112 of Alberta's $E P E A,{ }^{53}$ it is an offence for a "person responsible for the substance" to fail to take reasonable measures to repair, remedy, and confine the effects of a release as soon as that person becomes aware or ought to have become aware of the release.

Furthermore, Canadian courts have consistently taken a broad interpretive approach to the application of environmental legislation. For example, in R. v. Edmonton (City of), the Alberta Provincial Court analyzed the meaning of "charge, management or control” in the context of reporting a release under the EPEA. ${ }^{54}$ In that case, Judge Maher explained the meaning and intention of the definition:

In my view the phrase "charge, management or control" as it may relate to the pollutant, has a very broad ordinary meaning as well as a purposive meaning. The phrase is not restricted to immediate, it may be long term. It is not confined to physical, but extends to legal. It is not limited as to the time or location where the polluting activity takes place, but may include when and where the pollution consequence occurs. It is not restrained to the temporary or the usual, the perpetrator or the victim; it includes all. This is all consistent with the Legislature creating a wider class or category of possible reporters of environmental pollution.

The broad approach above is reflected in other Alberta decisions, ${ }^{55}$ and is of particular assistance in analyzing how different players in the crude by rail sector may be found to have been a person in "charge, management or control” of crude involved in an adverse incident and resulting spill or release. Such a broad approach is also instructive in analyzing how parent corporations that exercise some aspects of charge, management, or control of a subsidiary might be treated in the quasi-criminal context in connection with an environmental incident involving the subsidiary.

In most provinces, quasi-criminal offences are strict liability offences such that a defendant will be permitted to rely on due diligence as a defence. ${ }^{56}$ Unlike the situation involving a Ministerial Order, in most provinces a person charged with violating the provisions of the applicable environmental statute has to have acquiesced in, directed, or otherwise been involved in the carrying out of the offence to be found liable. If charged, a person generally has the ability to assert a due diligence defence. ${ }^{57}$ In many instances, a defendant who is able to demonstrate that it had an environmental management system in

Supra note 45. See also section 227, which renders contravention of section 112 an offence.

2006 ABPC 56, 20 CELR (3d) 1 at para 603.

See Imperial Oil Ltd v Alberta (Director, Enforcement \& Monitoring, Bow Region, Regional Services, Alberta Environment), [2002] 47 CELR (NS) 170 at para 47 (Alta Environmental Appeal Board), where the Board stated: "[t] $t$ he relevant definition of a 'person responsible' ... focuses on the person who caused or contributed to the pollution and, in our view, implements the 'polluter pays' principle advocated in section 2 of EPEA.” See also Legal Oil and Gas Ltd v Alberta (Minister of Environment), 2000 ABQB 388, 265 AR 341 at para 45 [Legal Oil], in which an individual was held liable as a person responsible by virtue of his position as the "President, boss, and manager, with exclusive control of the company's operations."

$56 \quad$ This defence was originally set out in $R v$ Sault Ste Marie, [1978] 2 SCR 1299.

57 The defence of due diligence is available to persons charged with most of the provisions under the $E P E A$, with the exception of those that occurred knowingly or with intent (see supra note 45, s 229). 
place to prevent the commission of the offence may be able to satisfy the requirements of a due diligence defence.

In some instances, however, quasi-criminal regulatory offences constitute absolute liability offences. Absolute liability offences do not permit an accused party to rely on a defence of due diligence. Rather, guilt of an accused party follows upon proof of the proscribed act. ${ }^{58}$ In New Brunswick, for example, all offences under the Clean Environment Act are absolute liability offences ${ }^{59}$ and persons charged under it would not be able to exculpate themselves by demonstrating that they took reasonable actions to prevent the offence from occurring.

Convictions under environmental statutes have resulted in jail sentences. However, in most instances convictions generally result in fines, which in recent years have been dramatically increasing. Under most environmental statutes, fines can be issued for each day on which the offence continues. ${ }^{60}$

\section{POTENTIAL LIABILITY OF DIRECTORS AND OFFICERS}

As previously noted, a Ministerial Order can be issued against any person who has or has had "charge, management or control” of a substance. In Alberta, this provision has been held to be expansive enough to include directors and officers of a corporation. ${ }^{61}$ Similarly, in the context of a single-purpose corporation, it could encompass shareholders and parent companies in circumstances where the government finds that they effectively had charge, management, or control of a substance or thing. Finally, section 232 of the EPEA imposes express quasi-criminal liability upon directors and officers of a corporation for the actions of the corporation in circumstances where the directors or officers were involved in the commission of the offence, regardless of whether the corporation has been charged or convicted. $^{62}$

However, like their corporation, directors and officers are entitled to raise a due diligence defence in the event they are charged. Although there is no set criteria to follow that will guarantee a person remains duly diligent, the case of $R$. $v$. Bata Industries $L t d .^{63}$ provides excellent guidance that is still applicable. In that case, the Court stated:

I ask myself the following questions in assessing the defence of due diligence:

Absolute liability offences have been determined not to violate principles of fundamental justice protected by the Charter so long as conviction would not impose the possibility of imprisonment: Lévis (City) v Tétreault, 2006 SCC 12, [2006] 1 SCR 420 at paras 17-19; Canadian Charter of Rights and Freedoms, Part I of the Constitution Act, 1982, being Schedule B to the Canada Act 1982 (UK), 1982, c 11 [Charter].

RSNB 1973, c C-6, s 34. This section states: "Every person other than an individual who commits an offence under this Act or the regulations commits an absolute liability offence."

60 For example, in New Brunswick, a fine not exceeding one million dollars may be issued for each day on which an offence continues: ibid, ss 33(1); 33(2).

$61 \quad$ See Legal Oil, supra note 55.

62 Section 232 of the EPEA, supra note 45 reads as follows:

Where a corporation commits an offence under this Act, any officer, director or agent of the corporation who directed, authorized, assented to, acquiesced in or participated in the commission of the offence is guilty of the offence and is liable to the punishment provided for the offence, whether or not the corporation has been prosecuted for or convicted of the offence. (1992), 9 OR (3d) 329 (Prov Div), var'd 14 OR (3d) 354 (Gen Div). 
(a) Did the board of directors establish a pollution prevention "system" as indicated in R. v. Sault Ste. Marie. i.e., was there supervision or inspection? was there improvement in business methods? did he exhort those he controlled or influenced?

(b) Did each director ensure that the corporate officers have been instructed to set up a system sufficient within the terms and practices of its industry of ensuring compliance with environmental laws, to ensure that the officers report back periodically to the board on the operation of the system, and to ensure that the officers are instructed to report any substantial non-compliance to the board in a timely manner?

I reminded myself that:

(c) The directors are responsible for reviewing the environmental compliance reports provided by the officers of the corporation, but are justified in placing reasonable reliance on reports provided to them by corporate officers, consultants, counsel or other informed parties.

(d) The directors should substantiate that the officers are promptly addressing environmental concerns brought to their attention by government agencies or other concerned parties including shareholders.

(e) The directors should be aware of the standards of their industry and other industries which deal with similar environmental pollutants or risks.

(f) The directors should immediately and personally react when they have notice the system has failed. $^{64}$

Pursuant to the above, having a reasonable pollution prevention system in place will be instrumental in minimizing any potential liabilities that directors and officers may face, both in the crude by rail context and otherwise.

\section{RAIL AND Storage SAFETy Legislation}

The possible application of federal and provincial transportation of goods and environmental protection legislation to a wide variety of crude by rail participants can be contrasted with other legislative regimes applicable to crude by rail operations that are somewhat narrower in scope, like those that only directly apply to a single stage or a single member of the crude by rail supply chain.

The overarching legislation governing rail safety federally is the Railway Safety Act, ${ }^{65}$ including the Railway Safety Management System Regulations. ${ }^{66}$ The RSA and the RSMS Regulations set out a panoply of requirements regarding the construction of railway works, the use of railway equipment, and railway operations, and, accordingly, their primary applicability is to carriers of crude oil by rail (railways). Given the broad definition of 
"railway" under the RSA, however, which includes "branches,” “depots,” "equipment," "stores," and "other things connected with the railway," other crude by rail project participants (for example, as co-owners of a crude transloading/storage facility) may also be subject to the RSA where they qualify as a person who "constructs, operates or maintains a railway." 67 Of note, the RSA allows the Minister of Transport, where he or she is of the opinion that there is an immediate threat to safe railway operations or the security of railway transportation, to issue an emergency directive ordering a railway: (1) to cease using certain railway works or railway equipment; or (2) to cease following or to follow a specific maintenance or operating practice. ${ }^{68}$ The $R S A$ and $R S M S$ Regulations also require railways to maintain and implement safety management systems.

Other regulations potentially applicable to the design and operation of crude by rail transloading or storage facilities include the Flammable Liquids Bulk Storage Regulations. ${ }^{69}$ In particular, these apply to the stationary bulk storage of flammable liquids, including crude oil, located on a right-of-way owned or leased by any railway company subject to the jurisdiction of the Canadian Transportation Agency (CTA), formerly the Canadian Transport Commission (although the FLBS Regulations still make reference to the latter). Generally, the FLBS Regulations set out design, location, construction, operation, and maintenance requirements for such installations, and will therefore directly bear on the design and operation of crude by rail storage and transloading facilities subject to CTA jurisdiction. The FLBS Regulations require the authorization of the CTA be obtained prior to construction or operation of bulk storage of flammable liquids facilities, and also set out certain procedural requirements regarding the loading and unloading of tank cars with flammable liquids. Related obligations include the duty to report immediately to the CTA any "fire, explosion, pipeline rupture or storage tank failure occurring on the installation, followed by a detailed report to the [CTA] within 30 days."70

\section{Potential Civil Liability to Third Parties}

\section{CAUSES OF ACTION}

In addition to possible liability under transportation of dangerous goods legislation, environmental protection legislation, and railway safety legislation, participants in crude by rail ventures also face potential civil liability to third parties impacted by adverse crude by rail incidents under multiple relevant common law causes of action, including negligence, nuisance, trespass, and strict liability (as provided in Rylands v. Fletcher ${ }^{71}$ ).

Generally speaking, such liability can arise in one of two contexts. First, it may arise in respect of operations at a crude by rail transloading or offloading facility, in the context of the receipt, handling, and storage of crude. Second, it may arise in the context of the transportation of crude by provincial and federal railways.

RSA, supra note 65 , s 4 .

Ibid, s 33.

CRC, с 1148 [FLBS Regulations], enacted pursuant to the Canada Transportation Act, SC 1996, с 10 [CTA].

FLBS Regulations, ibid, s 64.

(1868) LR 3 HL 330 [Rylands], discussed in Windsor v Canadian Pacific Railway Ltd, 2014 ABCA 108, 572 AR 317 at paras 17-24. 
Given this dichotomy, a number of relatively high-level observations can be made regarding the potential civil liability to third parties crude by rail participants face. One is that the identity of possible claimants in the context of an adverse incident at transloading facilities can be more reasonably predicted in advance. They are most likely to include (and perhaps even be limited to) current neighbors of the facility or individuals present at the facility at the time of the adverse incident. By contrast, potential claimants in the case of an adverse incident during transport will be largely determined by the location of the incident, neighboring development and property ownership, the surrounding environment, and possible bystanders, none of which can be forecast in advance with any meaningful specificity.

Somewhat similarly, the different types of claims or causes of action possibly arising in connection with adverse incidents occurring during the transportation of crude by rail can reasonably be anticipated to be potentially greater in number than in respect of adverse incidents occurring at transloading and storage facilities. In particular, whereas claims in the context of adverse incidents occurring at crude transloading and storage facilities could, where contained within or limited to the private property of the facility owner, conceivably be limited to negligence (for example, in the case of injuries to employees or other persons present), the suite of imaginable causes of action resulting from an adverse incident occurring during the transport of crude across private or public property is wider in scope, including negligence, nuisance, and trespass.

That said, generalizations such as these are only of so much utility, and the possible range of claimants and causes of action relating to an adverse crude by rail incident will, of course, turn on the particular circumstances of the incident. For example, where an unintended release of crude occurs in close proximity to a river or body of water, whether occurring at a transloading facility or during rail transport, additional possible claims include actions based on riparian rights (the right of property owners whose land borders a natural watercourse to the natural quality of such watercourse) by property owners downstream of the incident. ${ }^{72}$ It is also of course important to remember that adverse crude by rail incidents can lead to a wide variety of contractual claims, whether between the operator of a facility and its co-owner, producers and facility operators, or crude owners and crude transporters, to name only a few.

On the other hand, it is not unreasonable to anticipate that adverse crude by rail incidents may be less vulnerable to some of the difficulties which have traditionally hampered or frustrated claimants in suits based in whole or in part on alleged environmental damages or losses suffered, including: (1) establishing standing; (2) inconclusive scientific evidence or divided expert opinion; and (3) difficulties in in establishing causation or calculating damages (for example, long latency periods associated with injuries resulting from exposure to toxic substances). ${ }^{73}$ In particular, given the immediacy of materially adverse effects associated with crude by rail incidents, together with the well-understood nature and characteristics of the hazardous substance involved, the damages suffered or losses incurred 
as a result of the incident, as well as the significance of the injuries or property damages or losses suffered, should in many cases be capable of relatively ready ascertainment.

\section{CLASS ACTIONS}

Generally speaking, Canadian class action legislation requires that five elements be met in order for a class action to be certified. ${ }^{74}$ The class must be based on a legally recognized cause of action. The class must be composed of two or more people whose claims are sufficiently similar that they can be identified as a class. The claim must involve issues in common to all class members' claims. Progressing the claims of the class members via a class action must be the preferable procedure for advancing the resolution of the common issues. There must also be a representative plaintiff capable of fairly representing the interests of the class.

What does the spectre of class action proceedings mean for crude by rail participants in particular? For US or other international participants in the Canadian crude by rail sector, one is that Canada is increasingly being considered a class action "friendly" jurisdiction, particularly in comparison to its southern neighbor. ${ }^{75}$ By way of recent example, the Supreme Court of Canada confirmed that certification requires "some basis in fact" to conclude that each of the certification criteria has been met. ${ }^{76}$ This can be contrasted with US federal law, which requires US District Courts to conduct a "rigorous analysis" to determine if class action certification requirements are satisfied. ${ }^{77}$ As one analysis frames the matter, Canadian certification criteria "are broad, liberal, and predisposed toward certification, and the courts have readily followed suit."78

Perhaps more significantly, it is important to appreciate that adverse crude by rail incidents in many ways represent the type of occurrence perfectly suited to certification and class action litigation. As discussed by Justice MacPherson of the Ontario Court of Appeal in the context of certification arguments made in respect of the Bre-X Minerals scandal:

Disasters spawn litigation. Trains collide or derail, planes crash, ships sink, lakes and rivers become polluted, chemical factories explode, ordinary people eat, drink, wear or use unhealthy or defective products. People — sometimes hundreds, even thousands - are injured or killed by these events. When the crisis subsides, some of the victims turn to the courts for redress and compensation.

One of the modern mechanisms for dealing with the litigation fallout from major disasters is the class action. $^{79}$

$74 \quad$ McCarthy Tétrault, Defending Class Actions in Canada, 3d ed (Toronto: CCH Canadian, 2011) at 178205. For a discussion of certification of "authorization" in Quebec (as opposed to the common law provinces and territories), see McCarthy Tétrault, ibid at 206-11.

$75 \quad$ Ibid at 32-33.

76 See Infineon Technologies AG v Option consommateurs, 2013 SCC 59, [2013] 3 SCR 600; Sun-Rype Products Ltd v Archer Daniels Midland Company, 2013 SCC 58, [2013] 3 SCR 545; Pro-Sys Consultants Ltd v Microsoft Corporation, 2013 SCC 57, [2013] 3 SCR 477 at paras 99-105.

77 See Comcast Corporation v Behrend, 133 S Ct 1426 at 1432 (2013). See also McCarthy Tétrault, supra note 74 at 12-23 for a high-level comparative analysis of Canadian and United States class action law and jurisprudence.

$78 \quad$ McCarthy Tétrault, ibid at 31.

79 Carom v Bre-X Minerals Ltd (2000), 51 OR (3d) 236 at 238 (CA), leave to appeal to SCC refused, 28307 (18 October 2001). 
Stated somewhat more succinctly, derailments of crude shipments and the resulting property damage, as well as any associated personal injuries, will typically constitute single, discrete events giving rise to issues which will be common to the claims of all of those people who have suffered damages or injury, making adverse crude by rail incidents particularly well-suited for class action claims and proceedings, whether based in negligence, nuisance, trespass, strict liability, or otherwise. ${ }^{80}$

That said, not all possible adverse (or allegedly adverse) occurrences involving rail transportation will be appropriate for class action proceedings.

In Cuff v. Canadian National Railway Co., for example, the Alberta Court of Queen's Bench declined to certify a class action claim in negligence, nuisance, and strict liability following the derailment of 45 railway cars adjacent to the shore of Lake Wabamun (approximately $70 \mathrm{~km}$ west of Edmonton) and the resulting discharge of crude oil into the lake. ${ }^{81} \mathrm{CN}$ Rail responded with immediate remediation operations and the negotiation of compensation agreements with area residents suffering property damage costing approximately $\$ 100$ million. Nonetheless, the plaintiffs claimed that certain damages remained outstanding given the loss of enjoyment of the lake allegedly suffered. While the Court did not expressly disagree that some of such claims for damages might remain warranted, it noted that the voluntary remediation efforts of CN Rail and the compensation agreements negotiated with respect to the incident had the effect of removing many of the common issues that might otherwise have been shared by the plaintiffs, rendering such claims inappropriate for pursuit via class action. ${ }^{82}$

In Brooks v. Canadian Pacific Railway Ltd., the Court of Queen's Bench of Saskatchewan denied certification of a class action claim launched following the derailment of five railway cars carrying anhydrous ammonia (a hazardous substance) near downtown Estevan, Saskatchewan. ${ }^{83}$ Although three of the railcars tipped onto their sides, no anhydrous ammonia was released and no damage to property occurred (other than to CP Rail's own property), but city officials nonetheless evacuated approximately 175 local individuals and businesses for 44 hours for precautionary reasons. A number of the evacuees responded by filing the class action, arguing entitlement to damages for pure economic loss. The Court refused to certify the claim as a class action on a number of grounds. Amongst a number of other deficiencies, the Court noted that "while the proposed class is objectively identified, the class is not rationally related to all the claims of loss," and that "while there are some common issues, several of the proposed common issues are not common across the proposed class." 84

Similarly, in Roberts v. Canadian Pacific Railway, the British Columbia Supreme Court refused to certify a class action against CP Rail based on nuisance, negligence, and the strict

$80 \quad$ See McCarthy Tétrault, supra note 74 at 32. Note also that the judicial reception of mass tort claims in the US has been "more mixed.” See also Brimner v Via Rail Canada Inc (2000), 50 OR (3d) 114 (Sup $\mathrm{Ct} \mathrm{J}$ ), in which the passengers of a derailed train were certified as a class in respect of negligence and breach of contract claims further to a passenger train derailment near Thamesville, Ontario.

2007 ABQB 761, [2007] AJ No 1438 (QL).

Ibid at paras 29, 42-43.

2007 SKQB 247, 283 DLR (4th) 540.

Ibid at para 202. 
liability principles articulated in Rylands against CP Rail further to coal dust emanating from trains operated by the company along a 1,200 km length of track through the interior of the province. ${ }^{85}$ Amongst other things, the Court held that the plaintiff was unable to satisfy the "common issues" requirement given that the subject trains "pass through a vast expanse with tremendous diversity in terms of ecosystems, patterns of human settlement, and land use" with the result that "there is no basis to conclude that exposure to coal dust will be even throughout the Class Area." 86

On the other hand, there is no reason to assume that adverse incidents occurring at crude by rail transloading or storage facilities will not also be capable of being certified as class actions alongside incidents occurring during rail transport. In Windsor v. Canadian Pacific Railway Ltd., the Alberta Court of Queen's Bench certified a class action brought against CP Rail relating to a contaminant released by the company at a railway maintenance and repair facility in the Calgary area that resulted in nearby groundwater contamination and associated diminution in property values. ${ }^{87}$ The company appealed the certification on a number of grounds, including that the Court erred in allowing into the same class claimants in respect of whom different assessments of both causation and damages may have to be made. The Alberta Court of Appeal disagreed, holding that "[i]t is not fatal to certification to have both quantum and causation issues determined individually when the majority of the issues between the parties are common." ${ }^{88}$

\section{E. REGULATORY DEVELOPMENTS AND RELATED LEGAL CONSIDERATIONS}

\section{RECENT REGULATORY DEVELOPMENTS}

It is important to emphasize that the transportation of crude by rail is a dynamic area of commercial and legal practice. The acute focus of the public and law makers now trained on the transportation of crude by rail is leading to a rapid succession of developments in the regulation of the transportation of crude by rail, of which crude by rail participants should be both aware and responsive. The examples are numerous, and vary in both nature and potential significance.

Almost immediately following the tragedy at Lac-Mégantic, on 23 July 2013 the federal Minister of Transport issued an Emergency Directive pursuant to section 33 of the RSA, tightening operating rules to prevent runaways of trains handling dangerous goods. ${ }^{89}$ Many of these rules were intended to capture the most glaring operational deficiencies that became apparent following the accident at Lac-Megantic, and included requirements: (1) that any locomotive attached to one or more railcars carrying dangerous goods be operated by no fewer than two qualified persons; (2) that no such locomotive be left unattended; (3) that

2006 BCSC 1649, [2006] BCJ No 2905 (QL) [Roberts]; Rylands, supra note 71. Roberts, ibid at paras $6,14$. 2006 ABQB 348, 402 AR 162. 2007 ABCA 294, 417 AR 200 at para 33.

Transport Canada, "Emergency Directive Pursuant to Section 33 of the Railway Safety Act" (23 July 2013), online: Government of Canada <www.news.gc.ca/web/article-en.do?nid=829609>; RSA, supra note 65 . 
locomotive cabs be protected from unauthorized entry; and (4) that all brakes be fully applied when a locomotive is stopped.

This was followed in October 2013 by Protective Direction No. 31 imposing testing, labelling, and containment requirements on crude imported by rail or offered for transport by rail, and granting to Transport Canada the ability to request all such testing results. ${ }^{90}$ Twin Protective Directions issued in April 2014, on the other hand, mandated first that all persons transporting crude oil, gasoline, diesel, aviation fuel, or ethanol institute Emergency Response Plans (ERPs) within 150 days, and second, that the least crash-resistant DOT-111 tank cars be immediately removed from dangerous goods transportation service. ${ }^{91}$ Transport Canada instructed that the ERPs would be reviewed by the Transport of Dangerous Goods Directorate and, if effective, approved for use. It also instructed that all applicable DOT-111 tank cars be clearly marked with the words "do not load with dangerous goods in Canada."

These relatively targeted developments in the regulation of the transportation of crude by rail are also being joined by broader, more systemic regulatory reviews and developments.

On 18 November 2013, for example, the Minister of Transport requested that the Standing Committee on Transport, Infrastructure and Communities conduct a new in-depth review of the Canadian regime regarding the safe transportation of dangerous goods and the role of Safety Management Systems across all modes of transportation, including rail. ${ }^{92}$ The Minister requested that an interim report be submitted by June 2014, and that the Committee's finding be presented in a final report by December 2014. Several months later, Transport Canada announced the launch of a comprehensive review of the third-party liability and compensation regime applicable to rail transport. ${ }^{93}$ The announcement was joined by the release of an associated discussion paper, and included the Department's plan to conduct meetings regarding rail transport liability with industry and other stakeholders toward the goal of revising legislated insurance requirements to ensure sufficient funds will be available to adequately compensate potential victims, pay for any remediation costs, and protect taxpayers in the event of adverse rail transportation incidents.

Other developments in the regulation of the transportation of crude by rail are being driven in part by the cooperation of Canadian and US authorities in the desire to ensure uniformity of standards across both jurisdictions and what is in fact, if not in law, an integrated panNorth American railroad infrastructure system.

Transport Canada, "Protective Direction No. 31" (17 October 2013), online: Alberta Ministry of Transportation < www.transportation.alberta.ca/Content/docType521/Production/Protective\%20Direct ion $\% 2031 \% 20 \% 28$ Signed\%29.pdf $>$.

91 Transport Canada, "Protective Direction no. 33" (23 April 2014), online: Transport Canada <www. tc.gc.ca/eng/mediaroom/protective-direction-33-7494.html>; Transport Canada, "Protective Direction no. 34" (23 April 2014), online: Transport Canada < www.tc.gc.ca/eng/mediaroom/protective-direction34-7493.html>

92 House of Commons, Standing Committee on Transport, Infrastructure and Communities, Evidence, 41st Parl, 2nd Sess, No 2 (18 November 2013) (Hon Lisa Raitt).

93 Transport Canada, "Comprehensive Review of the Third Part Liability and Compensation Regime for Rail: Discussion Paper” (10 February 2014), online: Transport Canada < www.tc.gc.ca/eng/policy/acgacgb-review-liability-rail-3106.html>. 
On 11 January 2014, the government of Canada proposed new Regulations Amending the Transportation of Dangerous Goods Regulations (Update of Standards) which would introduce new standards for certain rail tank cars, replacing existing standards under the TDGR and imposing new consignor record keeping and certification obligations. ${ }^{94}$ The proposed regulations would introduce new tank car design requirements, including for new DOT-111 tank cars, to align with the requirements already widely adopted in the US. These also include design standards implemented in American Association of Railways (AAR) Circular Letter CPC-1232, including: (1) new requirements for half head-shields; (2) increased thickness of tank car shell and heads; and (3) top-fitting protection for new DOT111 tank cars. ${ }^{95}$ Following Lac-Mégantic, the Transportation Safety Board of Canada (CTSB) has also been working with the US National Transportation Safety Board to issue recommendations to government to decrease other risks associated with the transportation of crude by rail, including requiring railway companies to conduct route planning and risk analysis, a risk mitigation practice officially prescribed by Transport Canada in April 2014 by way of emergency directive. ${ }^{96}$

Finally, certain developments in the regulation of the transportation of crude by rail are being driven by voluntary initiatives undertaken by crude by rail participants.

In February 2014, the US freight rail industry (through the AAR) reached a deal with the United States Department of Transportation (USDOT) to put into place voluntary safety standards for the shipping of crude by rail. ${ }^{97}$ Under the terms of the deal reached between the USDOT and the AAR, the rail industry will put into place, by July 2014: (1) a number of measures designed to improve both the safety of rail tank cars that carry crude oil; and (2) emergency response plans tailored to rail accidents involving crude. Additional measures to be adopted by US railways as part of the deal are to be rolled out progressively. By March 2014, for example, railroads will be expected to have been performing at least one additional internal rail inspection each year above the minimum required under federal railroad law for each main line on which trains moving 20 or more carloads of crude oil travel. They will also be expected to have been conducting at least two high-tech track geometry inspections on these lines, despite those inspections not being mandated by law. By April 2014, trains transporting crude by rail will be expected to have been equipped with power sources and two-way telemetry devices that enable the application of emergency brakes from both ends of the train for increased deceleration capability.

Supra note 36.

SOR/2014-152 (Regulatory Impact Analysis Statement), (2014) C Gaz II, 1797.

Transport Canada, "Emergency Directive Pursuant to Section 33 of the Railway Safety Act: Rail Transportation of Dangerous Goods” (23 April 2014), online: Transport Canada <www.tc.gc.ca/ eng/mediaroom/emergency-directive-railway-7492.html>.

97 Association of American Railroads, Press Release, "Freight Railroads Join U.S. Transportation Secretary Foxx in Announcing Crude by Rail Safety Initiative” (21 February 2014), online: AAR < www.aar.org/ newsandevents/Press-Releases/Pages/Freight-Railroads-Join-U-S-Transportation-Secretary-Foxx-inAnnouncing-Industry-Crude-By-Rail-Safety-Initiative.aspx>. 


\section{ADDITIONAL LEGAL CONSIDERATIONS \\ RELATED TO REGULATORY DEVELOPMENTS}

\section{a. Regulatory Compliance and Civil Liability}

The developments in the regulation of the transportation of crude by rail considered above are interesting and important in and of themselves. They directly inform the conditions in which the transportation of crude by rail occurs and the regulations and potential liabilities applicable thereto. But it is important to appreciate that developments such as these may also have implications with respect to potential civil liability to third parties faced by crude by rail participants.

Take, for example, the voluntary adoption by the railway industry of standards more onerous than those imposed by regulation, such as the voluntary standards jointly announced by the AAR and the USDOT in February 2014. While these may not constitute a hard prescription that railways are legally required to abide by, they nonetheless represent standards that may be applied to the transportation of crude by rail in other legal circumstances, such as a civil claim against a railway carrier for negligence following an incident causing significant personal property loss or personal injury. In particular, the claimants could argue that such voluntary standards are indicative of industry "best practices" when articulating the scope and substance of the duty of care owed by railway carriers to those potentially affected by their operations.

The case is analogous with route planning. As noted above, Transport Canada in April 2014 issued an emergency directive requiring carriers transporting dangerous goods to conduct risk assessments regarding different "key routes" (being any track on which, over the period of a year, is carried 10,000 or more tank cars loaded with dangerous goods) for the purpose of, amongst other things, identifying and comparing alternative routes for safety and security, including for considerations such as environmentally sensitive areas along routes, population densities along routes, and emergency response capabilities along routes. It is therefore arguable that, although carriers are not yet required by law to use lower-risk routes when transporting dangerous goods, the decision to use a higher-risk route in the face of a reasonably comparable alternate lower-risk route could be held against a carrier should an adverse incident actually occur. Of course, any argument that railway companies in Canada should be expected to route potentially dangerous shipments around higher-risk areas must be balanced against reasonable costs associated with such routing. As noted by both CN Rail and CP Rail, routing railway shipments around major cities such as Winnipeg, Toronto, or Montreal would be "prohibitively expensive" given that "routing options in Canada are limited." 98

Similarly, it is also important to appreciate that strict compliance by crude by rail participants with all applicable regulatory operating directions will by no means preclude liability to third parties for a breach of a duty of care. As noted by the Supreme Court of

98 Kim Mackrael, “Can’t avoid big cities when moving dangerous goods, railways say” The Globe and Mail (3 April 2014), online: <www.theglobeandmail.com/news/national/cant-avoid-big-cities-whenmoving-dangerous-goods-railways-say/article17793755/>. 
Canada in Ryan v. Victoria (City), a case in which, coincidentally, the Court rescinded a previous limitation of liability enjoyed by Canadian railroads, "[l]egislative standards are relevant to the common law standard of care, but the two are not necessarily co-extensive." 99 As further noted by the Court:

For more than 90 years, railway companies have benefited from a "special rule" at common law which placed them in a privileged position within the law of negligence. As long as a railway complied with the requirements imposed upon it by applicable statutes, regulations and administrative orders, it was under no further obligation — absent extraordinary circumstances — to act in an objectively reasonable manner.

With the abolishment of the special rule, the correct principles can now be stated more clearly

Where a statute authorizes certain activities and strictly defines the manner of performance and the precautions to be taken, it is more likely to be found that compliance with the statute constitutes reasonable care and that no additional measures are required. By contrast, where a statute is general or permits discretion as to the manner of performance, or where unusual circumstances exist which are not clearly within the scope of the statute, mere compliance is unlikely to exhaust the standard of care. This approach strikes an appropriate balance among several important policies, including deference to legislative determinations on matters of railway safety, security for railways which comply with prescribed standards, and protection for those who may be injured as a result of unreasonable choices made by railways in the exercise of official authority. 100

Stated somewhat differently, the "fact that a statute prescribes or prohibits certain activities may constitute evidence of reasonable conduct in a given situation, but it does not extinguish the underlying obligation of reasonableness."

In this light, it is not difficult to imagine instances where difficult questions could arise regarding whether reasonable risk mitigation measures were undertaken to guard against the risks posed by the transportation of crude by rail.

Following the issuance of Protective Direction No. 31, and after sustained pressure from municipalities, Transport Canada on 20 November 2013 issued Protective Direction No. 32 requiring railway companies to provide yearly aggregate information on the nature and volume of dangerous goods (including crude oil) to the designated Emergency Planning Official of each municipality through which the railway transports dangerous goods, subject to certain exceptions. ${ }^{102}$ For certain railway companies there is also a requirement to advise of any significant change to the information provided as soon as practicable after the change occurs. To the disappointment of some municipalities, this reporting will be historical rather 
than forward looking, and will not come with any new powers given to municipalities to be able to refuse trains carrying dangerous goods from passing through their territory. Rather, the purpose of the revised regulations, according to the Federation of Canadian Municipalities, is to be able to allow first responders to better identify trends and better prepare for the possibility of different types of rail accidents involving dangerous goods. However, this requirement nonetheless raises the possibility that railway operators could be held to account for failing to adequately engage with local authorities and to update local authorities regarding operational changes as quickly or regularly as may arguably be warranted.

Improvements in safety procedures and equipment standards raise similar issues. In April 2014, Transport Canada announced that all DOT-111 tank cars used to transport crude oil that do not meet the standard published in January 2014 in the Canada Gazette must be either phased out or retrofitted within three years. ${ }^{103}$ Compliance with this prescription will therefore be mandatory and, should any such inferior tank cars be utilized by a carrier to transport crude past this date, it is clear that a duty of care will have been breached. That said, should an adverse crude by rail incident occur involving such inferior tank cars prior to this date, the timelines set by Transport Canada will not prevent an argument (including by any injured parties) that the carrier could have phased out its use of the tank cars at a more rapid pace.

\section{b. Statutory Causes of Action and Related Remedies}

In addition to the above, it is important to appreciate that developments in regulatory requirements may bring with them additional associated potential liability to third parties. The EPEA, for example, establishes a civil cause of action for the benefit of any person who suffered damage or loss as a consequence of behavior constituting an offence under the EPEA and for which the defendant is convicted. It states: "where a person is convicted of an offence under this Act, any person who suffers loss or damage as a result of the conduct that constituted the offence may, in a court of competent jurisdiction, sue for and recover from the convicted person an amount equal to the loss or damage proved to have been suffered."104

Importantly, the effect of this provision is to relieve plaintiffs of the requirement to establish that the defendant owed them a duty of care in the circumstances and that the defendant failed to satisfy such duty of care. ${ }^{105}$ Rather, all that the plaintiff must establish is that the damage or loss was suffered as a result of the conduct constituting the offence. The CEPA includes a similar provision, which provides as follows:

Any person who has suffered loss or damage as a result of conduct that contravenes any provision of this Act or the regulations may, in any court of competent jurisdiction, bring an action to recover from the person who engaged in the conduct

(a) an amount equal to the loss or damage proved to have been suffered by the person; and 
(b) an amount to compensate for the costs that the person incurs in connection with the matter and proceedings under this section. ${ }^{106}$

Both the EPEA and the CEPA also provide that where a person is convicted of an offence, the applicable court may, at the time of sentencing and upon the application of an aggrieved person, order the offender to pay compensation to the applicant for loss of or damage to property suffered as a result of the offence. ${ }^{107}$

Novel compensation regimes and remedies such as these have in part been developed to assist victims of environmental injuries in obtaining compensation for damages and losses suffered. They also provide that, where an adverse crude by rail incident involves an offence under regimes of this nature, the offender or offenders will face potential statutory liability to third parties in addition to common law liability to such third parties, such statutory liability including the substantive and procedural advantages available to aggrieved third parties described above. Furthermore, although it has been noted that "relatively few" Canadian statutes confer civil causes of action in connection with the contravention of their provisions, it has also been noted that "the number of such statutes has been increasing in recent years." 108

It is therefore not inconceivable that the ongoing scrutiny and review of the regulation of crude by rail will prompt the addition of civil cause of action provisions and related remedies in legislation not currently incorporating such compensatory regimes. For example, while the TDGA matches the EPEA and CEPA in authorizing the court to issue an order requiring a person convicted under it "to provide compensation, whether monetary or otherwise, for any remedial action taken or damage suffered by another person arising out of the commission of the offence," 109 it does not currently include an associated statutory cause of action provision as do the other statutes.

\section{F. LEgAL Liability CASE StUdy: LAC-MÉGANTIC}

\section{THE EVENTS SurRounding THE DERAILMENT AND EXPLOSION}

It is not necessary to consider the legal liabilities associated with the transportation of crude by rail in the abstract. Rather, given that crude by rail in North America has already suffered a number of well-publicized adverse incidents, these provide case studies capable of illuminating the various legal regimes considered above, including, not least, the catastrophe that befell southern Quebec in July of 2013. The material details of the LacMégantic tragedy are now generally well known.

Montreal, Maine \& Atlantic Railway (MM\&A) — formed in 2003 when Rail World Inc. of Rosemont, Illinois acquired the assets of the Bangor and Aroostook Railroad - owned and operated approximately 825 km of railroad track in Quebec, New Brunswick, Vermont, and Maine. The railroad track passing through Lac-Mégantic originates in Côte Saint-Luc 
— on the island of Montreal — and skirts southern Quebec before crossing the US border to end at Brownville Junction in Maine. CP Rail was contracted by a midstream marketer to transport crude produced from the Bakken formation from New Town, North Dakota to Côte Saint-Luc, and from there to a local New Brunswick, refinery-owned railroad, responsibility for the latter leg subcontracted to MM\&A. ${ }^{110}$

On 5 July 2013, at approximately 11:00 p.m., the MM\&A train carrying the Lac-Mégantic shipment was stopped in Nantes, Quebec, $11 \mathrm{~km}$ west of Lac-Mégantic. The train was approximately 1,500 $\mathrm{m}$ long, weighed approximately 10,300 tons, was being pulled by five locomotives, and included 72 DOT-111 tank cars carrying roughly 7.7 million litres of crude oil. The track upon which the train was travelling is an "excepted track" and prohibited from being used to transport specific categories of hazardous materials. When the train was stopped, it was positioned at an elevation of $515 \mathrm{~m}$ and on a descending 1.2 percent gradient slope. Prior to retiring to a local hotel for the night, the sole operator applied the air brake of the lead locomotive, powering down the remaining four locomotives.

Shortly thereafter, residents of Nantes noticed a significant amount of smoke trailing from the train's first locomotive and call 911. The Nantes fire department attended the scene at 11:45 p.m., extinguishing a small fire in the locomotive reportedly caused by a ruptured fuel line or oil line in the locomotive. In accordance with procedure, the fire department powered down the running engine to prevent the fire from accessing the locomotive's fuel. The fire department was joined at 11:50 p.m. by two track maintenance employees of MM\&A, but not the sole operator. Once the fire was completely extinguished, the Nantes fire department departed the scene, followed by the two MM\&A employees.

The MM\&A train then began to creep downhill, eventually rolling uncontrolled into the centre of Lac-Mégantic, derailing in the town centre at 1:14 a.m. The locomotives and several cars detached from the train and stopped approximately a half mile east of the derailment, while 63 tank cars derailed in Lac-Mégantic's centre, igniting and exploding. Forty-seven individuals lost their lives, and 2,000 residents were evacuated from the area to prevent further injury. Thirty buildings in the centre of town were destroyed, including the town's library and historic bank. Over 100 businesses were destroyed, displaced, or rendered inaccessible. Nearly six million litres of crude were released in and onto, and contaminated nearby soil, land, and water, while an estimated 100,000 litres of oil spilled into the Chaudière River, with oil later being recorded as having reached as far as $100 \mathrm{~km}$ downriver from the derailment site.

By January 2014, more than 75,000 cubic metres of contaminated soil had been trucked from a 31-hectare decontamination site in the centre of Lac-Mégantic to a specially constructed storage facility outside of town, and more than 46 million litres of oily water had been pumped out of Lake Mégantic and the Chaudière River. ${ }^{111}$ By April 2014, the federal

110 Note that, in its subsequent objections to environmental orders issued in connection with the derailment, CP Rail has argued that it was directed to subcontract to MM\&A by the owners of the subject crude, and that it should therefore not be liable for events flowing from that decision.

111 Monique Beaudin, "Huge scope of Lac-Mégantic cleanup comes into focus," Montreal Gazette (6 January 2014), online: <www.montrealgazette.com/news/Huge+scope+Mgantic+cleanup+comes+into +focus/9348298/story.html>. 
government spent $\$ 60$ million to support response and recovery efforts and had committed up to $\$ 95$ million for decontamination efforts. ${ }^{112}$ Total remediation costs are estimated at \$200 million. ${ }^{113}$ Testing conducted on Bakken crude by US authorities following the disaster revealed it to be of greater volatility than typical crude, as well as capable of ignition at lower temperatures. ${ }^{114}$

\section{The Resulting Regulatory Response And Class Action}

On 29 July 2013, an environmental protection order (EPO) was issued by the Quebec Minister of Sustainable Development, Environment, Wildlife and Parks under the Province's Environmental Quality Act to MM\&A and its US parent company, as well as to the alleged owner of the fuel and its parent company, namely Western Petroleum Company (WPC) and World Fuel Services Corporation (WFSC). ${ }^{115}$ The EPO was subsequently modified on 14 August 2013 to include CP Rail and World Fuel Inc. (the ultimate parent company to WPC and WFSC), ${ }^{116}$ amidst media reports that the owners and operators had insufficient funds available to respond to the remediation costs. ${ }^{117}$

The modified EPO alleged that World Fuel Inc. had agreed to sell the fuel to the eventual downstream customer, Irving Oil, and as such was also an owner of the fuel alongside its subsidiaries. The modified EPO also alleged that CP Rail remained the party primarily responsible for transporting the crude even though its subcontractor, MM\&A, was in possession of the crude at the time of the accident. Requirements imposed by the EPOs on the named corporations included: (1) recovering the crude and other contaminants discharged by the derailment; (2) preventing the further migration of the discharged crude and other contaminants; (3) complying with remediation instructions given by the Minister; (4) submitting a comprehensive action plan and timetable; and (5) confirming with the Minister the parties' intention to comply within 24 hours of service of the orders.

Each of the six companies named in the modified EPO gave notice of their intention to contest their inclusion in the order, making competing arguments regarding who owned or was most responsible for the crude at the time of the accident. The companies also collectively argued that the EPOs were improperly issued given that their authorization is limited to emergency situations, which was no longer the case when they were issued approximately three and five weeks following the accident. ${ }^{118}$ Resolution of this dispute is also taking place in the shadow of complex cross-border insolvency proceedings involving MM\&A, its owner, and their affiliates. ${ }^{119}$

Transport Canada, News Release, “Transport Canada takes action in response to TSB's initial LacMégantic recommendations” (23 April 2014) online: Government of Canada <news.gc.ca/web/articleen.do?nid=841129>.

Monique Beaudin, “Someone has to pay to clean this up,” Montreal Gazette (18 January 2014) A3 (Factiva) [Beaudin, "Someone has to pay”].

“Officials issue safety warning on crude oil,” Montreal Gazette (3 January 2014) A7 (Factiva).

Québec, Développement durable, Environnement, Faune et Parcs, No 628, Ordonnance (29 July 2013). Québec, Développement durable, Environnement, Faune et Parcs, No 628-A, Ordonnance Modifiée (14 August 2013).

Beaudin, "Someone has to pay," supra note 113.

The authors note that this matter was scheduled to be heard 15 April 2014 but that, as of the date of writing, they have not yet been able to review any decisions issued further thereto.

Jim Middlemiss, “Tracking the road to ruin” InHouse (16 December 2013), online: Canadian Lawyer <www.canadianlawyermag.com/4930/Tracking-the-road-to-ruin.html>. 
The class action filed in the Superior Court of Québec has been made on behalf of all persons and entities (including both natural and legal persons)

residing in, owning or leasing property in, operating a business in or being employed by a person resident in or located in Lac-Mégantic, and/or were physically present in Lac-Mégantic ... who have suffered a loss of any nature or kind relating to or arising directly or indirectly from the train derailment that took place on July 6, 2013 in Lac-Mégantic. ${ }^{120}$

The respondents listed in the claim are numerous, and include: (1) MM\&A, its parent company, Rail World Inc., and a number of their affiliates; (2) various executive officers of the Rail World Inc. group of entities, including Edward Burkhardt, the president of Rail World Inc. and several of its affiliates; (3) various Bakken producers of the crude composing the Lac-Mégantic shipment; (4) various entities who provided transloading services in North Dakota in connection with the Lac-Mégantic shipment; (5) various lessors and suppliers of the railcar tankers used to transport the Lac-Mégantic shipment; (6) various midstream marketers and lessees of railcar tanks used to transport the Lac-Mégantic shipment; (7) various refiner entities as purchasers and intended recipients of the Lac-Mégantic shipment; (8) CP Rail as the other carrier involved in the Lac-Mégantic shipment; and (9) Transport Canada and the Canadian Transportation Agency.

The suite of allegations made by the petitioners against the named respondents are equally extensive and diverse:

(1) Allegations levied against MM\&A and Rail World include that: (a) the companies' rail operations were conducted with significant staffing and safety procedure deficiencies and in general disregard for industry best practices; and (b) the companies disregarded the fact that the Lac-Mégantic shipment used older and non-reinforced DOT-111 that were unsuited for highly combustible liquids and which are prone to rupture and explode in the event of a derailment.

(2) Allegations levied against the producers include that they: (a) failed to conduct any adequate well-site testing to determine the composition of the Bakken crude and the resulting appropriate classification and labelling of the crude such that the hazard classification was not an accurate classification of the cargo being shipped; (b) failed to ensure that raw well product was adequately processed to remove any significant content of volatile vapours, gases, and highly flammable light ends prior to transport; and (c) allowed volatile vapours, gases, and/or highly flammable light ends to be added to the crude prior to transport.

(3) Allegations levied against the transloading services providers, the tanker lessors, the marketers and tanker lessees, and the refiners include that they: (a) failed to take reasonable care to ensure that the crude was properly classified and labelled; (b) neglected to take reasonable care to ensure that the crude was not transported in DOT- 
111 tanks or that the crude was only transported in DOT-111 tanks that were properly reinforced to improve safety in the event of a collision; and (c) neglected to hire a safe and qualified railway operator with a positive safety record and an adequately trained staff.

(4) Allegations levied against CP Rail include that the company: (a) chose to ignore well known safety concerns related to MM\&A in engaging MM\&A as subcontractor for the Lac-Mégantic shipment; (b) intentionally disregarded what it knew to be the improper classification and labelling of the crude composing the Lac-Mégantic shipment to allow it to subcontract the shipment to MM\&A; (c) chose to route the shipment to New Brunswick through MM\&A’s less maintained and more dangerous route rather than using a longer, but much safer, alternate CN Rail route; and (d) overlooked visible defects in the lead locomotive in assembling the train in the company's Côte Saint-Luc interchange yard.

(5) Allegations levied against Transport Canada and the Canadian Transportation Agency include: (a) the failure to properly police and sanction MM\&A, a company described by the petitioners as having the poorest safety record of any railroad company in North America; (b) allowing hazardous goods to be transported on an "excepted track” by MM\&A; (c) allowing MM\&A to operate trains with only a single conductor, rather than two operators as is customary in the industry; and (d) failing to ensure that MM\&A and its affiliates were appropriately and adequately insured in the event of an accident.

In total, the varied and inclusive allegations made by the petitioners remain only that allegations - and remain subject to the evidence of the parties and the scrutiny of the court. They also remain subject to further evolution. As noted in the now fourth amended petition, the respondents named and the facts presented are as known currently and that, "[a]s new facts emerge throughout the various investigations of the governmental bodies, the Petitioners reserve their right to amend" their pleadings. ${ }^{121}$ Participants in the crude by rail sector will therefore continue to watch the Lac-Mégantic proceedings with great interest, particularly should the petitioners' claim receive certification (or “authorization” as termed under the law of Quebec) and proceed to judicial determination (rather than settlement).

\section{Contractual Arrangements in Crude by RaIL AND A SURVEY OF SELECT ISSUES}

\section{A. Governing AgreEments}

As previously noted, there is no such thing as a standard crude by rail project, and the characteristics of each - including their location, the facilities involved, the project participants, and project governance - may vary greatly depending on the circumstances, including, in particular, the needs of the producer(s) involved, as well as existing and available transportation and storage infrastructure. 
For some producers, the transportation of crude by rail is very much a collective of supply chain issues from wellhead to buyer, requiring the coordination of the production, ancillary transportation, and storage of crude, together with capacity at a transloading facility and the availability of railcars at that facility and the routing to the market or buyer. Layered over these logistical requirements is the importance of managing the risks that manifest when trains do not run on time, most notably demurrage charges for idle railcars or capacity charges for unused transloading facility capacity. Other producers or marketers may face all or any number of the foregoing depending upon the points at which transfer of custody and title take place.

Each crude by rail project will therefore involve a different combination of contractual agreements as determined by the foregoing context, and typically include some or all of the following: (1) construction, ownership, and operating agreements; (2) rail terminal services agreements; (3) tank or storage services agreements; (4) facility connection agreements; (5) facility leases; and (6) rail transportation services agreements.

Where the construction of significant new infrastructure is necessary and is undertaken by two or more entities, this will likely necessitate a construction, ownership, and operating agreement. This agreement will be among the owners of the crude by rail project facilities, and will typically address, amongst other things: (1) the percentage ownership interests of the project participants in the project facilities; (2) the formation of a management committee to oversee the material operations of the facilities; (3) the appointment of an operator to conduct the day-to-day operations of the facilities; (4) the preparation and approval of operating budgets and expenditures; (5) the approval of, and participation in, expansions to the facilities; and (6) assignments of interest in the facilities.

The main agreement governing the provision of services by the project participants to crude producers and other customers of the project will be a rail terminal services agreement or transloading services agreement. This agreement will establish, amongst other things: (1) the transloading capacity to which the customer is entitled; (2) the fees applicable to the transloading services; (3) the term of the services; and (4) any preferential rights of the customer to future expansions of facility capacity. Depending upon the players involved, the initial capital costs associated with building a transloading facility can be underpinned, in whole or in part, by firm commitments from facility users, with those that commit often able to negotiate preferred terms as founding customers.

A rail terminal services agreement will typically be joined by (or incorporate the terms of) a tank or storage services agreement pursuant to which the customer will be entitled to store crude at the facility between the time of delivery and the time of loading for rail transport.

Where the facility is located on lands not (jointly) owned by the facility owners, a lease will be required. Similarly, where the facility must be connected to local pipeline infrastructure to allow for delivery of product by crude producers and other customers to the facility, an interconnection agreement or connection services agreement may be required. Finally, a rail transportation services agreement will need to be executed between the owners of crude that has been loaded onto rail by the facility and the railway companies or companies that will be transporting the crude from the facility. 


\section{B. Discussion OF SELECT ISSUES}

\section{TRANSLOADING FACILITIES AND SERVICES AND RiSK ALLOCATION}

It is a trite observation that a primary means by which risk is allocated amongst parties to commercial agreements in the oil and gas sector is through the use of indemnity provisions. ${ }^{122}$ This is done for a number of different reasons and in a number of different ways.

Indemnity provisions assist in providing certainty to commercial arrangements by specifying which parties are responsible for which identified risks and subject to what conditions or limitations. They also allow parties to allocate responsibility for risks in a manner which may diverge significantly from that which would result from the unrestrained application of the common law and equity. Indemnity provisions can specify that they are the sole remedies available to the parties, coupled with a waiver of the right to recourse under the common law or equity. They can remove any entitlement of the parties to consequential or indirect damages as well as extend protection to third-party beneficiaries, including the officers, directors, and other employees of the parties. Indemnities can entitle a person to compensation even in the case of their own negligence. Indemnities may also overrule or nullify the common law requirement that losses or damages suffered by a party must have been "reasonably foreseeable" in order for the disaffected person to be entitled to compensation. Finally, indemnities can be subject to any number of conditions or limitations, including minimum liability thresholds as well as maximum liability caps.

Indemnities can also be structured in different ways with different triggers. On one side of the spectrum reside fault-based indemnity structures. In such instances, one party covenants to indemnify the other party for damages or losses suffered by the other party resulting from the breach by the first party of its obligations under the agreement, such as a breach of representations or warranties or a breach of a covenant to perform certain activities or not to perform certain other activities. Conversely, no-fault indemnity structures do not depend on the actions of the parties but rather entitle one or more of the parties to indemnification by the other parties upon the incurrence of certain identified damages or losses, for example, the allocation of environmental liabilities to the purchaser in an oil and gas asset purchase and sale agreement. That said, no-fault indemnity structures typically include certain carve outs, including: (1) damages or losses suffered resulting from the gross negligence or wilful misconduct of the party claiming indemnification; and (2) damages or losses suffered which are covered by insurance held by the party claiming indemnification. Finally, there is nothing to prohibit a single agreement from incorporating both fault-based and no-fault indemnity structures, and this is indeed often the case.

Turning toward the material risks associated with the transportation of crude by rail identified above - namely liability under applicable legislation as well as to third-party claimants - the question then becomes determining the various possible approaches to allocating such risk pursuant to indemnification provisions in different applicable project agreements. Towards this end, it is useful to note that the crude by rail project agreements

122 For a detailed discussion of this topic, see Nick Kangles et al, "Risk Allocation Provisions in Energy Industry Agreements: Are We Getting it Right?” (2011) 49:2 Alta L Rev 339. 
described above generally fall into one of two categories. First, co-ownership and operating agreements between facility owners. Second, service agreements between various different sets of crude by rail participants, including transloading or storage service agreements between facility owners and producers or other owners of crude, as well as rail transportation service agreements between railway companies and producers or other owners of crude. Furthermore, different approaches to risk allocation and indemnification are generally appropriate under each set of arrangements.

As has been noted, co-ownership and operating agreements "attempt to balance a continuing relationship whereby both parties will benefit from the efficient ongoing development of the jointly owned asset," with the result that the agreement must "create a system whereby parties may appropriately share in not only the proceeds of development and operation, but also the risks associated therewith."123 The most common means of achieving this goal is the adoption of a liability regime "pursuant to which the operator is indemnified by all of the co-owners of the asset in proportion to their respective ownership interest therein,"124 and there is generally no reason why this structure is not also appropriate in respect of the co-ownership and operation of crude by rail project facilities. This is a no-fault indemnity structure and, as discussed above, will typically carve out the operator's right to indemnification for damages or losses either resulting from the gross negligence or wilful misconduct of the operator or which are covered by insurance maintained by the operator in respect of joint operations. Other issues typically provided for in this structure include the defence of claims filed against the facility owners, including the amount of claims the operator may settle in its sole discretion (as opposed to being required to obtain the approval of the management committee), as well as the right of non-operators to be represented by their own counsel should they so prefer.

Given the current considerably dynamic state of the regulation of crude by rail, as well as continued uncertainty regarding the capacity, cost, and completion date of proposed additional pipeline infrastructure, one particular point of risk allocation to be carefully considered by project co-owners is the standard of effort required of the party charged with constructing a new transloading facility and the consequences of the failure to meet an agreed in-service date. Simply put, different crude by rail projects will be of different complexity, and many of the crude by rail projects proposed or under construction have experienced development delays. ${ }^{125}$ Different projects will also be exposed to different commercial risks, including different regulatory risks and market risks. Another prime concern will therefore be ensuring the recoupment of capital expenditures, as well as agreeing to the circumstances in which expansions to transloading capacity may be pursued, at whose cost and for whose benefit. Related items that can provide fodder for heated negotiations include preferential rates for anchor tenants, preferential rights for additional or newly vacant capacity, and the ability to sublease rights to transloading service capacity.

Service agreements pertain to a relationship significantly different than that of co-owners, namely that between a service provider and its client or customer. Amongst other things, one 
result of this dynamic is the frequent desire of the parties to apportion liability and the right to indemnification pursuant to a fault-based risk allocation regime. Stated differently, parties to service agreements commonly agree that they should each "be responsible for a breach of their own contractual obligations and should be able to hold their commercial counterparties liable in the event of a similar, reciprocal breach." ${ }^{126}$ Another result of this dynamic is the necessity to establish clearly the performance obligations and other covenants of each of the parties the breach of which will give rise to a right to indemnification.

In the case of crude by rail transloading or storage service agreements, this will include the obligation of the facility operator to provide the services in a manner consistent with prudent industry practices and in compliance with applicable laws. However, given the prescriptions of the TDGA and the other statutes and regulations discussed above, consideration should also be given to specifically including the obligation of the producer or other owner of the crude to: (1) ensure that the crude delivered to the facility is accompanied by all required certificates of analysis, labelling, and other materials and data required by prudent industry practices and applicable law; and (2) immediately notify the operator of any changes to the information or materials provided in connection with delivered crude. The parties should also be certain to make clear that title to delivered crude at all times remains with the producer or other owner of the crude (unless the parties agree otherwise), as well as that the facility operator assumes no responsibility for the state, condition, or nature of railcars used to transport the crude from the facility, the responsibility for which remains exclusively with the producer or other owner of the crude (again, unless circumstances dictate otherwise or the parties agree otherwise).

Specific to rail transloading or terminal service agreements, parties may wish to pay particular attention to so called "stem" costs associated with movement of crude by rail, primarily made up of detention or demurrage charges. Demurrage, in the context of rail, is the charge levied on a party responsible for the detention of rolling stock, and is intended to act as an incentive for efficient operation of the rolling stock. When considering a price quote for transportation between two points, industry participants may wish to consider, and allocate, the ultimate charges that may have to be borne to complete delivery, including typical rail demurrage and other demurrage-type fees that may be charged by transloading facilities, private sidings, and other third parties.

In addition — and again in consideration of the currently dynamic nature of the regulation of crude by rail — it may be advisable for the parties to rail transloading or storage service agreements to allocate liability for any increased costs in providing the services attributable to complying with regulatory developments arising after the execution of the agreement. This is not, strictly speaking, a matter typically addressed through indemnification provisions, but rather through adjustment mechanisms incorporated into fee calculation and payment provisions. For example, such regulatory risk is typically borne by the recipient of the services, which in the case of rail transloading or storage service agreements may involve allocating the increased compliance costs to each of the customers of the project facilities in proportion with their entitlement to the facility’s capacity. 


\section{ARRANGEMENTS BETWEEN SHIPPER AND CARRIER}

A different set of considerations are applicable to commercial terms, risk allocation, and indemnification under rail transportation service agreements between owners of crude and railway companies. Among these will be the application of the $C T A^{127}$ and the Railway Traffic Liability Regulations. ${ }^{128}$ Shippers looking to secure railway transportation services in Canada can face a challenging commercial proposition. Historically, railways were subject to heavier regulation than they are today, including the regulation of freight rates. However, a recent period of deregulation has left Canada's primary railways (CN Rail and CP Rail) to operate today as a duopoly with comparatively little restriction on their ability to set the commercial terms and freight rates for the provision of railway transportation services. In particular, section 137(1) of the CTA provides that a railway company may "limit or restrict its liability to a shipper" by means of a written agreement. ${ }^{129}$ This is a relatively new development in the history of the regulation of rail transportation whereby "the matter of limiting a carrier's liability has now been essentially deregulated and that the parties are free to negotiate on this issue and contract as to the basis upon which they will do business."130 Competition between the railways, certain legislative protections (such as section 112 of the CTA which mandates that rates be "commercially fair and reasonable”), and the relative bargaining power of the counterparty are the primary limiting factors on a railway's ability to dictate commercial terms and rates.

Generally speaking, pursuant to the CTA, shippers can secure railway transportation services in two ways: (1) pursuant to a posted tariff published by the railways (section 117); or (2) under the terms of a transportation service contract, commonly called a "confidential contract” (section 126).

Securing transportation service under a published railway tariff offers some advantages to shippers. Service is usually readily available and efficient to confirm and schedule. Moreover, a shipper may not be subject to a minimum volume commitment shipping under a tariff. Statutory protections for shippers remain available in the CTA, including service level complaints pursuant to section 116, complaints for unreasonable charges under section 120.1, inter-switching rights under sections 127 and 128, and final offer arbitration under sections 159 through 169.3. However, the rates secured under a tariff may be higher relative to those which can be negotiated in a confidential contract. Further, other than statutory protections afforded to shippers under the CTA and RTLR, and limited shipper remedies under the rules and regulations (if any) included in a posted tariff, shippers have little in the way of liability protection. Moreover, provided the railway complies with the thirty-day notice period in section 119 of the CTA, the railways are free to amend (increase) a tariff at any time, giving shippers less cost certainty. 
In general, shippers will prefer to secure service pursuant to a confidential contract, particularly in circumstances where the shipper can generate competition between the railways. This desire has been reflected in the recent amendments to the CTA in June 2013, which added sections 126 and 169.31. ${ }^{131}$ These new shipper remedies allow shippers to request a service level agreement, and in the event that the parties cannot agree to contractual terms, allow the shipper to submit the matter to arbitration. Of particular benefit to smaller shippers and shippers who are unable to generate competition between the railways, these provisions provide shippers a mechanism to get the railways to the negotiating table and offer service agreements. However, the negotiation of a service agreement is not a carte blanche positive for shippers; it also affords the railways an opportunity to reduce their obligations and secure concessions from shippers. In this context, consideration should be given to, among other things: (1) minimum volume commitments; (2) the right of the railway to interchange with other carriers; (3) service levels; and (4) limitations of liability and the constraint of statutory remedies.

In respect of the last of these issues, the provisions of the RTLR should be kept in mind given that there remain certain legislated circumstances in which a railway carrier will not be liable for any loss or damage in respect of goods being transported, including where the loss or damage results from "any act, negligence or omission of the shipper or owner of the goods." ${ }^{132}$ Similarly, the RTLR provides that a carrier will not be liable to any loss or damage caused by dangerous goods where the shipper does not disclose in writing to the carrier the nature of the goods. ${ }^{133}$ Amongst other things, these provisions limit the ability of the parties to allocate certain risks to carriers and therefore highlight the importance that shippers or consignors of crude should be cognizant of, and comply with, their transportation of dangerous goods duties and obligations.

\section{DISRUPTIONS OF CRUDE BY RAIL OPERATIONS}

\section{a. Intervention by Regulators}

In March 2014, Transport Canada announced a temporary 90-day direction requiring CN Rail and CP Rail to transport a minimum aggregate of one million tonnes of Canadian grain per week, approximately double the amount then being transported by the two companies. ${ }^{134}$ The move came after protracted complaints by Canadian grain producers, grain handling companies, and politicians that the agricultural industry was being under-serviced by the railway companies, leading to a large backlog in wheat, canola, barley, and other grains, and resulting in the inability of farmers to take full advantage of relatively strong market prices for these commodities as well as the loss of market share to US competitors not faced with similar difficulties. The direction imposed the possibility of a $\$ 100,000$ penalty per day where CN Rail or CP Rail failed to meet their quota.

Fair Rail Freight Service Act, SC 2013, c 31, ss 8, 11.

RTLR, supra note 128, s 5(1)(e).

Ibid at 16(1).

Order Imposing Measures to Address the Extraordinary Disruption to the National Transportation System in Relation to Grain Movement, SOR/2014-55. 
Although not intending to disavow the order, the railway companies responded by arguing that they were being unfairly singled out and blamed for "the shortcomings of the entire supply chain,” and by explaining that the year's massive crop yield (being approximately 40 percent greater than the previous year's harvest) and the winter's extreme cold periods had made normal operations impossible, particularly given that train lengths are curtailed during winter months to ensure they can be stopped safely and the fact that equipment failures are more common in cold conditions. ${ }^{135}$ The companies also explained that while they were prepared to meet the government's demands, doing so would require the cooperation of other role players in the agricultural supply chain, including grain elevator operators and port terminal operators. ${ }^{136}$

The temporary directive was followed by the announcement less than three weeks later of the Fair Rail for Grain Farmers Act (FRGFA) which, amongst other things, enshrined the government's ability to impose minimum grain shipping quotas on railways. ${ }^{137}$ The move was immediately condemned by CN Rail and CP Rail who argued that the FRGFA would skew market forces, lead to reduced investment in Canada's rail sector, and expose the sector to increased competition by US railways without the benefit of reciprocity under US legislation. ${ }^{138}$ Other critics highlighted the interventionist nature of the legislation and its essential effect of favouring rail shipments of grain to the disadvantage of other commodities commonly shipped by rail, including (in addition to crude oil) food, coal, metal and minerals, forest products, and manufactured goods.

Although neither of these developments were undertaken in direct response to the rapid increase in the transportation of crude by rail over the last several years, this chronicle nonetheless raises a number of important issues for crude by rail participants. First, it highlights that crude by rail transportation capacity is subject to market and regulatory forces largely outside the control of crude by rail project participants, including as a result of the fact that: (1) crude is but one of a multitude of commodities shipped by rail in Canada; and (2) given their essentially dual-monopoly position, CN Rail and CP Rail are subject to government regulation of a nature generally inapplicable to other midstream oil and gas service providers. Second, it raises the following question: how should the risk of government intervention in the management of railway capacity of the type exemplified by the FRGFA and the temporary direction that preceded it be allocated in commercial agreements governing the relationship of crude by rail participants?

The initial temporary directive was issued pursuant to section 47(1) of the CTA, which provides as follows:

Eric Atkins, “Ottawa gives railways grain-moving quota” The Globe and Mail (7 March 2014), online: $<$ www.theglobeandmail.com/report-on-business/ottawa-takes-aim-at-grain-backlog-with-tough-newtransport-rules/article17367492/>; Eric Atkins, "Railways fire back over grain shipments" The Globe and Mail (12 March 2014), online: <www.theglobeandmail.com/report-on-business/cps-hunter-harrisonirate-over-ottawas-grain-moving-order/article 17455456/>.

Ibid.

SC 2014, с 8.

Josh Wingrove \& Kathryn Blaze Carlson, "CN calls Ottawa's move to clear grain backlog heavyhanded" The Globe and Mail (26 March 2014), online: <www.theglobeandmail.com/report-onbusiness/ottawa-enacts-new-rules-to-force-railways-to-ship-grain/article17682587/>; Josh Wingrove, "CP adds to criticism of Ottawa's move to ease grain backlog" The Globe and Mail (27 March 2014), online: $<$ www.theglobeandmail.com/report-on-business/cp-adds-to-criticism-of-ottawas-move-to-easegrain-backlog/article17712442/>. 
Where the Governor in Council is of the opinion that

(a) an extraordinary disruption to the effective continued operation of the national transportation system exists or is imminent, other than a labour disruption,

(b) failure to act under this section would be contrary to the interests of users and operators of the national transportation system, and

(c) there are no other provisions in this Act or in any other Act of Parliament that are sufficient and appropriate to remedy the situation and counter the actual or anticipated damage caused by the disruption,

the Governor in Council may, on the recommendation of the Minister and the minister responsible for the Bureau of Competition Policy, by order, take any steps, or direct the Agency to take any steps, that the Governor in Council considers essential to stabilize the national transportation system, including the imposition of capacity and pricing restraints. ${ }^{139}$

The FRGFA, on the other hand, amended both the Canada Grain Act ${ }^{140}$ and the CTA to, amongst other things: (1) extend the temporary 90-day direction requiring CN Rail and CP Rail to transport a minimum aggregate of one million tonnes of Canadian grain per week through to August 2014; and (2) grant the Governor in Council the authority, on the recommendation of the Minister of Agriculture and the Minister of Transport, to specify the minimum amount of grain that CN Rail and CP Rail must transport during any period within a crop year that begins on or after 1 August 2014.

The CTA does not define what is meant by "extraordinary disruption" or the "national transportation system” as employed in section 47(1). It does, on the other hand, declare that:

\footnotetext{
a competitive, economic and efficient national transportation system that meets the highest practicable safety and security standards and contributes to a sustainable environment and makes the best use of all modes of transportation at the lowest total cost is essential to serve the needs of its users, advance the well-being of Canadians and enable competitiveness and economic growth in both urban and rural areas throughout Canada. $^{141}$
}

Furthermore, the CTA states that these objectives will be best achieved when, amongst other things, "competition and market forces, both within and among the various modes of transportation, are the prime agents in providing viable and effective transportation services." ${ }^{142}$

Coupled with the requirements of section 47(1) itself, these principles suggest that government intervention in the transportation sector, including the operations of federal railways, should be an option of last resort, and that the liberal exercise of section 47(1) would attract vulnerability to administrative challenge on the basis of jurisdictional 
overreach. However, the very existence of section 47(1), as well as the tabling of the FRGFA, serve as unmistakable reminders that, regardless of the growing importance of the transportation of crude by rail to the vibrancy of the Canadian economy, the oil and gas sector still remains only a single industrial sector reliant for its well-being on railway infrastructure. They also highlight that, given that railway infrastructure is generally incapable of either expeditious expansion or adaptation, regulatory risk in the form of government intervention amidst materially adverse or unforeseen developments in wider market conditions appears to be an unavoidable component of participation in the crude by rail sector.

That said, although somewhat new to oil and gas participants in crude by rail projects, the risk of government intervention is not fundamentally novel. Rather, being essentially a possibility “outside normal business risk," regulatory risk of this nature qualifies as a species of risk typically addressed through force majeure provisions. ${ }^{143}$ A number of different approaches are available.

In the case of rail transloading and/or storage service agreements, the parties can make clear that a force majeure event includes governmental actions or directives that restrain or limit a party's ability to perform its obligations, including the ability of a facility operator to provide storage capacity promised to the customer under the agreement (for example, resulting from impeded offtake of crude by rail carriers). In this case, for example, the parties could specify: (1) which portion of the applicable fees and payments the customer remains liable for and for what period of time; and (2) the manner of allocation of newly available storage capacity amongst different customers of the facility during the continuance of the force majeure event. In the case of rail transportation service agreements, on the other hand, the parties should take into consideration the provisions of section 5(1)(f) of the RTLR. This provides that a carrier shall not be liable for any delay in the transportation of goods that results from "an authority of law," a term which can be reasonably interpreted to capture transportation delays resulting from government intervention in railway operations, whether by means similar to the FRGFA or otherwise, and which could therefore have the effect of nullifying force majeure provisions or other risk allocation mechanisms which seek to impose a different structure.

\section{b. Intervention by the Public}

In addition to possible intervention in crude by rail operations by government regulators, it is also important to recognize that rail transport operations are vulnerable to, and have in the past been interfered in by, the intentional actions of the public. In particular, in a number of previous occasions rail shipments have been halted by preplanned physical blockades organized by public interest groups, including First Nations groups.

In August 1990, for example, members of the Long Lake 58 First Nation erected a blockade across a portion of railway belonging to CN Rail passing through the First Nation's 
reserve in northern Ontario. The stated purpose of the blockade was to show support for the Oka crisis then ongoing in Quebec as well as to highlight that the First Nation's claimed lands had never been the subject of treaty negotiations with the federal government. In April 2008, by contrast, Six Nations protesters blocked a stretch of CN Rail line in a show of support for four Mohawk Indians who were arrested during a protest in Tyendinaga, Ontario, earlier in the month, and which protest had been ongoing since March 2007.

More recently, in late 2012 and early 2013, the “Idle No More” movement instigated dozens of rail line blockades, including one near Kingston, Ontario, that led to court proceedings and the decision in Canadian National Railway Co. v. Doe. ${ }^{144}$ First Nations protesters erected a blockade across CN Rail's Toronto to Montreal mainline disrupting both passenger and freight service. CN Rail responded promptly, applying for an interim injunction within four and a half hours of the initial blockade and receiving an order directing authorities to remove the blockade a mere four hours later.

In the Court's decision, Justice Brown applied the test germane to the granting of interim injunctions as articulated in RJR-MacDonald ${ }^{145}$ to the circumstances of the rail blockade, considering: (1) whether there was a serious issue to be tried; (2) whether the applicant was likely to suffer irreparable harm should the injunction not be granted; and (3) the balance of convenience of the parties involved. Towards this end, Justice Brown had little difficulty finding in favour of CN Rail on each count, noting, amongst other things:

The evidence filed by $\mathrm{CN}$ demonstrated an overwhelming case that the protesters were trespassing on its property and were tortiously interfering with the use of the main line by itself and VIA.

To simply set out above the evidence of [CN witness] about the impact of the blockade is to establish that the conduct of the protesters had caused and would continue to cause irreparable harm to CN, VIA and those who use the main line for personal and freight transportation.

On a standard analysis, the balance of convenience overwhelmingly favoured CN. Simply put, the protesters had no legal right to be doing what they were doing.

That conclusion does not change because the protesters, according to [CN witness], contended that they were blocking the main line to show support for First Nations chiefs in their upcoming meeting with Prime Minister Harper. While expressive conduct by lawful means enjoys strong protection in our system of governance and law, expressive conduct by unlawful means does not. No one can seriously suggest that a person can block freight and passenger traffic on one of the main arteries of our economy and then cloak 
himself with protection by asserting freedom of expression. The Canadian Charter of Rights and Freedoms does not offer such protection. ${ }^{146}$

Not all railway blockades have been dealt with as efficiently. Just two weeks prior to the John Doe ordeal, Justice Brown had issued an order to remove a similar blockade on a spur line near Sarnia, Ontario, in Canadian National Railway Co. v. Plain. ${ }^{147}$ The court order to disband the protest and blockade had also been expeditiously granted in this case, but with the difference that it remained unenforced by local Sarnia authorities for twelve days. In granting the order, Justice Brown voiced his frustration with the delay in enforcement as well as with the Sarnia Police Department's explanation for its deferment:

[L]ocal police agencies cannot ignore judicial orders under the guise of contemplating how best to use their tactical discretion. Such an approach would have the practical effect of neutering court orders. It is not the purpose of a court order simply to initiate talks or consultations between the police and those whom the court has found to have breached the law. A court order is not one amongst several chips to be played in an ongoing contest between the police and transgressors of legal rights. On the contrary, a court order is intended to initiate the process of bringing unlawful conduct to an end in a short period of time so that the harm which the court has found to be irreparable is brought to an end. ${ }^{148}$

What is the practical result or lesson from this precedent for crude by rail project participants? While none of the episodes considered above involved crude by rail operations, they do illustrate the potential for rail transportation operations to be subject to potentially significant and protracted disruption by the public. Furthermore, given the reality that the oil and gas industry (including the oil sands industry) often faces frequent opposition by certain interest groups, including environmental activists, these concerns may be somewhat amplified.

Also, while the above episodes may lead some readers to assume that it is the sole responsibility and entitlement of railway companies to seek injunctions to remove rail blockades, other crude by rail participants should appreciate that this is not strictly the case. While it makes considerable sense that railway companies will want and are best placed to respond immediately to blockades of rail traffic, where such response is less than prompt, there is nothing to prevent other affected crude by rail participants from instigating injunction proceedings in their own name where they meet the requisite standing requirements (such as ownership of assets threatened by the blockade). There is therefore no reason why crude by rail participants other than railway carriers cannot conduct risk analyses with such concerns in mind, as well as develop mitigation strategies and emergency response plans tailored toward such potentialities.

Much like in respect of possible government intervention in rail operations, crude by rail participants can also anticipate and provide for the risk of public interruption of railway operations through appropriate force majeure provisions, and towards this end the wording of $R T L R$ section 5(1) is again noteworthy. In particular, whereas the reference in section 
5(1)(f) to "an authority of law" would appear to restrain the ability of parties to allocate risk of government intervention in railway operations to the railway carrier, no subclause of section 5(1) appears similarly to restrict the allocation of risk attributable to public interruption of railway operations to railway carriers.

\section{CONCLUding REMARKS}

As discussed, the transportation of crude by rail involves a wide variety of legal and commercial considerations, not all of which can be considered in detail in a single academic article. So too do the commercial and legal forces shaping the growth of crude by rail remain in flux as new developments constantly trigger and inform public opinion as well as industry and government reaction. The result is a multi-faceted and dynamic area of law that should continue to challenge legal counsel in different and interesting ways for many years ahead. Not all of these challenges will be entirely new, however. They may in fact seem quite familiar in the first instance, thereby attracting familiar treatment, whether in the context of joint venture, construction, ownership and operation, off-take, or marketing arrangements; it is not unreasonable to argue that, from an owner or operator perspective, in many ways a crude transloading project is just another midstream infrastructure and service arrangement, or that, from a producer or marketer perspective, rail is just another pipeline. However, as we have attempted to highlight in this article, crude by rail operations bring with them a number of distinctive characteristics - including applicable commercial drivers, applicable legal regimes, the participation of regulated railway carriers, and vulnerability to governmental and public interference - not all of which will be pertinent to what at first blush may appear to be analogous oil and gas arrangements, and the consequences of which may merit careful consideration. 